\title{
Crosstalk of Multi-Omics Platforms with Plants of Therapeutic Importance
}

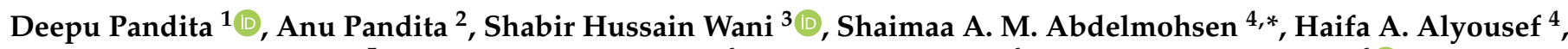 \\ Ashraf M. M. Abdelbacki ${ }^{5}$, Mohamed A. Al-Yafrasi ${ }^{6}$, Fahed A. Al-Mana ${ }^{6}$ and Hosam O. Elansary ${ }^{6}$ \\ 1 Government Department of School Education, Jammu 180001, Jammu and Kashmir, India; \\ deepupandita@gmail.com \\ 2 Vatsalya Clinic, Krishna Nagar, New Delhi 110051, Delhi, India; dt.anunischal46@gmail.com \\ 3 Mountain Research Centre for Field Crops, Sher-e-Kashmir University of Agricultural Sciences and \\ Technology of Kashmir, Khudwani Anantnag 192101, Jammu and Kashmir, India; \\ shabirhussainwani@gmail.com \\ 4 Physics Department, Faculty of Science, Princess Nourah bint Abdulrahman University, \\ Riyadh 84428, Saudi Arabia; haalyousef@pnu.edu.sa \\ 5 Applied Studies and Community Service College, King Saud University, Riyadh 11451, Saudi Arabia; \\ aabdelbacki@ksu.edu.sa \\ 6 Plant Production Department, College of Food and Agriculture Sciences, King Saud University, \\ Riyadh 11451, Saudi Arabia; mlyafrasi@ksu.edu.sa (M.A.A.-Y.); falman@ksu.edu.sa (F.A.A.-M.); \\ helansary@ksu.edu.sa (H.O.E.) \\ * Correspondence: shamohamed@pnu.edu.sa
}

\section{check for} updates

Citation: Pandita, D.; Pandita, A.; Wani, S.H.; Abdelmohsen, S.A.M.;

Alyousef, H.A.; Abdelbacki, A.M.M.; Al-Yafrasi, M.A.; Al-Mana, F.A.;

Elansary, H.O. Crosstalk of

Multi-Omics Platforms with Plants of Therapeutic Importance. Cells 2021, 10, 1296. https://doi.org/10.3390/ cells10061296

Academic Editor:

Suleyman Allakhverdiev

Received: 19 February 2021

Accepted: 10 May 2021

Published: 23 May 2021

Publisher's Note: MDPI stays neutral with regard to jurisdictional claims in published maps and institutional affiliations.

Copyright: (C) 2021 by the authors. Licensee MDPI, Basel, Switzerland. This article is an open access article distributed under the terms and conditions of the Creative Commons Attribution (CC BY) license (https:// creativecommons.org/licenses/by/ $4.0 /)$.

\begin{abstract}
From time immemorial, humans have exploited plants as a source of food and medicines. The World Health Organization (WHO) has recorded 21,000 plants with medicinal value out of 300,000 species available worldwide. The promising modern "multi-omics" platforms and tools have been proven as functional platforms able to endow us with comprehensive knowledge of the proteome, genome, transcriptome, and metabolome of medicinal plant systems so as to reveal the novel connected genetic (gene) pathways, proteins, regulator sequences and secondary metabolite (molecule) biosynthetic pathways of various drug and protein molecules from a variety of plants with therapeutic significance. This review paper endeavors to abridge the contemporary advancements in research areas of multi-omics and the information involved in decoding its prospective relevance to the utilization of plants with medicinal value in the present global scenario. The crosstalk of medicinal plants with genomics, transcriptomics, proteomics, and metabolomics approaches will be discussed.
\end{abstract}

Keywords: medicinal plants; multi-omics platforms; genomics; transcriptomics; proteomics; metabolomics

\section{Introduction}

\subsection{Medicinal Plants}

The welfare of humankind depends on 12\% of Earth's approximately 300,000 [1,2] to 400,000 plant species. Plant-based herbal medicines have been utilized for more than 5000 years. In the post-Neolithic period, approximately $60 \%$ of plants were reported to have medicinal properties [3]. Medicinal plants produce active metabolites or compounds of pharmacological importance for humankind [4]. Payne et al. [5] reported that only 5000 plant species from 250,000-300,000 were thoroughly studied for their medicinal value. Both small, narrow-ranged species and trees have therapeutically vital compounds [6,7]. Traditional medicinal plants are widely exploited in various regions of the world or across different continents, for instance, in South America, Asia and Africa [8], and in diverse civilizations $[9,10]$. For generations, ethno-medicine has been utilized by around $60 \%$ of the world population for their healthcare needs [11]. In prehistoric times when the medicinal properties of herbs were being explored [12-14], their scientific relevance, experimental 
potentiality, molecular mechanisms of medicinal value and emerging omics technologies applicability were unknown. The isolation of the bioactive compound "morphine" from the medicinal plant Papaver somniferum L. was the first reported in the early 1800s [15]. Countries such as Korea, China, India and Japan are leading the scientific investigation and validation of the fundamental principles of traditional medicines [16]. The World Health Organization (WHO) has catalogued 21,000 medicinal plants the world over. Out of these, 2500 species are of Indian origin, because of which India is known as the main producer of medicinal plants [17]. The WHO states that up-to $80 \%$ of the population of the developing countries depend principally on drugs of plant origin $[18,19]$. The WHO estimates that plant-based medicines provide principal healthcare for around 3.5-4 billion citizens globally [20]. The International Union for Conservation of Nature and World Wildlife Fund estimated that universally, above 50,000 plant species find use in medicinal purposes [21,22]. Around $25 \%$ of pharmaceuticals have a direct or indirect plant-based origin $[23,24]$. Global Industry Analysts (GIA) hold the opinion that the worldwide plant and herbal supplement market by the year 2020 will be worth USD 115 billion [25]. The WHO reports that the present need of herbal drugs is USD 14 billion per year, and by the year 2050, it will reach to USD 5 trillion [26]. Medicinal plants have been used in Indian therapeutic systems from time immemorial. Indian Medicine Systems include systems of medicine of Indian origin, such as Ayurveda (2559 herbs), Siddha (2267 herbs), Unani (1049 herbs), Sowa-Rigpa (671 herbs), Yoga, Naturopathy and Ethno-botanical Folk (6403 herbs), or those that came to Indian land from exterior areas and became enriched and incorporated into Indian culture, such as homeopathy (460 botanicals), which came to India in the 18th century [27]. The Indian Traditional Medicine System (Ayurveda) is gaining global acceptance. Approximately 25,000 efficient plant-based formulations are exploited within India. The trading of authenticated therapeutic plants and their products universally is worth approximately USD 60 billion. The annual profits of Ayurveda-based medicines in the global market are around USD 813 million [28]. Consequently, the Indian market is the heart of therapeutic plant trading, with a computable trade of around USD 140 million per annum. In 2010, the international export of plant-based and natural ingredients was worth around USD 33 billion and was anticipated to reach USD 93 billion by the year 2015, whereas the export of Indian medicinal plants and their products was predicted to be USD $\sim 0.2$ billion. Besides the global business, the worldwide trade of medicinal plants in India generates revenue of USD 1.6-1.8 billion [29]. India contributes only $2.5 \%$ of the annual USD 60 billion that constitutes the total worldwide herbal market. In spite of the rich legacy of Ayurvedic literature and the huge biodiversity of medicinal plants, India is still fighting with the potential market demands [29]. Herbaceous plant species (86 genera of 29 families) of Jammu province [30] and 105 medicinal plant species (36 families) from diverse niches of the district of Samba in the Union Territory of Jammu and Kashmir are used for medicinal purposes [31]. There are about 41 dicotyledonous plant species (29 families) [32] and 13 monocotyledonous angiospermic plant species (of 5 families) in the Union Territory of Jammu and Kashmir which are useful in the healing of diabetes mellitus [33].

\subsection{Omics Technologies}

Modern day omics approaches, which include genomics, transcriptomics, proteomics and metabolomics, are becoming extremely significant for the identification and characterization of vital gene-protein-metabolite networks, new drug metabolites, complete genomes, transcriptomes, and proteomes of medicinal plants, and the responses of human cells to drugs or whole ethno-botanical plants for the medicinal use and large-scale production of plant-derived medicines [34-37]. The next generation sequencing (NGS) technique has increased the deep transcriptome studies of medicinal plants, the crosstalk between gene expression co-responses and the accumulation of metabolites. The concept of "guilt-by-association" states that genes undergoing co-expression lead to biosynthesis of metabolites which show accumulation analogous to levels of the co-expression of genes [38]. 
The metabolomics approach, along with the functional genomics of gene products from ethno-medicinal plants, accelerates the discovery of new biosynthetic pathways of various bioactive metabolites. This has improved the prospective discovery and generation of products with pharmaceutical significance. Artemisinin (antimalarial drug) was first enhanced by the breeding of Artemisia annua L. with novel hybrids with high-yielding abilities so as to gain a robust cropping system, and secondly in a re-engineered microbial host by the reconstitution of the biosynthetic pathway of artemisinin, which was obtained after the sequencing of its genome [39]. The crosstalk of omics with the ethno-botanical approach was studied in a non-plant bioengineered host via the detection of a string of FAD2 phytochemicals after the transcriptomics and metabolomics of developing seeds that amass abnormal fatty acids [40]. Vitis vinifera L. multi-omics (transcriptomics, metabolomics and genome-wide microarray analysis) identified 238 genes and 2012 metabolites that are upregulated by UV-C irradiation. This supports the concept that stilbene biosynthesis encourages transcription factor-mediated regulation [41]. Genes of the morphine biosynthetic pathway in Papaver somniferum L. have been identified mostly by omics approaches [42,43]. The integration of transcriptome and genetic approaches identified an alkaloid biosynthesis gene cluster in the genome of Papaver somniferum L. [44]. In an editorial by Chen [45], phytochemicals such as carotenoids, flavonoids, lignans, and phenolic acids were reported as having been analyzed via high-throughput tools. The mechanistic insights into the bioactivities of these substances, and roles in disease treatments, profiling, extraction, identification and biotechnology, and focus on the gene transfer and nanoparticles have been explored. Another paper focused on studies of medicinal plants with bioinformatics-assisted tools. Their focus was a case study of multi-omics data-based workflow for the Dendrobium medicinal plant, and it incorporated very few details on the genomics, transcriptomics, proteomics and metabolomics of other important medicinal plants [46]. The potential applications of metabolomics as well as analytical techniques, statistical approaches and bioinformatics tools help us to understand the system-wide effects of Thai traditional medicine [47]. The frequency and distribution of the 47,700 microsatellites or simple sequence repeats (SSRs) from 109,609 expressed sequence tags (ESTs) of 11 medicinal plants with antidiabetic potential were studied for their potential as biomarkers for cross transferability [48]. Our present review is novel in terms of being comprehensive and detailed, focusing mainly on the studies of multi-omics technologies in medicinal plants. The review also highlights the chemical structures of medicinal metabolites and/or drugs/synthetic derivatives of some important medicinal plants, along with their medicinal properties. The objective of this review paper is to merge the omics-based approaches with the scientific investigations in various medicinal plants with representative case studies. This will update our awareness of natural-product-based drugs from various plants of therapeutic significance, and the prolonged exploitation of plant pharmaceutical resources.

\section{Omics in Medicinal Plants}

High-throughput omics platforms such as genomics, transcriptomics, proteomics and metabolomics (Figure 1) generate big data. Big data can be used for the prediction of secondary metabolic pathways of various therapeutic plants, to discover the genes involved in the biosynthesis of biologically active metabolites and to probe the plant genome and evolution. Medicinal plants develop novel traits to adapt to shifting environments for an improved life. The hypothesis-based and big data-based investigations of medicinal plants combine plant-based analysis, biotechnology and omics approaches to improve the life of man. The Medicinal Plant Genomics Consortium and genome-guided research [49,50], the Medicinal Plant Transcriptome Project [51], the 1000 Green Plant Transcriptome Project [52], etc., will help in the identification of various plant biosynthetic pathways and their evolution, especially in the discovery of new pathways originating as gene clusters in Oryza sativa L., barley [53] and poppy. In poppy, an antitumor noscapine (alkaloid) biosynthetic pathway of a 10-gene cluster positioned over $401 \mathrm{~kb}$ of genomic sequence was found [44]. Advanced RNA sequencing techniques enable us to study the expression profiles of en- 
zymes and transcription factors on a global scale. The database of metabolomics and transcriptomics of 14 medicinal plants (http://metnetdb.org/mpmr_public/ accessed on 17 November 2020) is accessible for the development of a hypothesis regarding the role of genes [54]. The research area of metabolomics was developed after genomics, transcriptomics and proteomics, and deals with all the metabolites of a cell [55]. In Glycyrrhiza uralensis Fisch. ex DC. (licorice), two cytochrome P450 genes of the glycyrrhizin biosynthetic pathway were detected [56], and these direct the microbial generation of glycyrrhetinic acid and triterpene saponin, which is a natural sweetener.

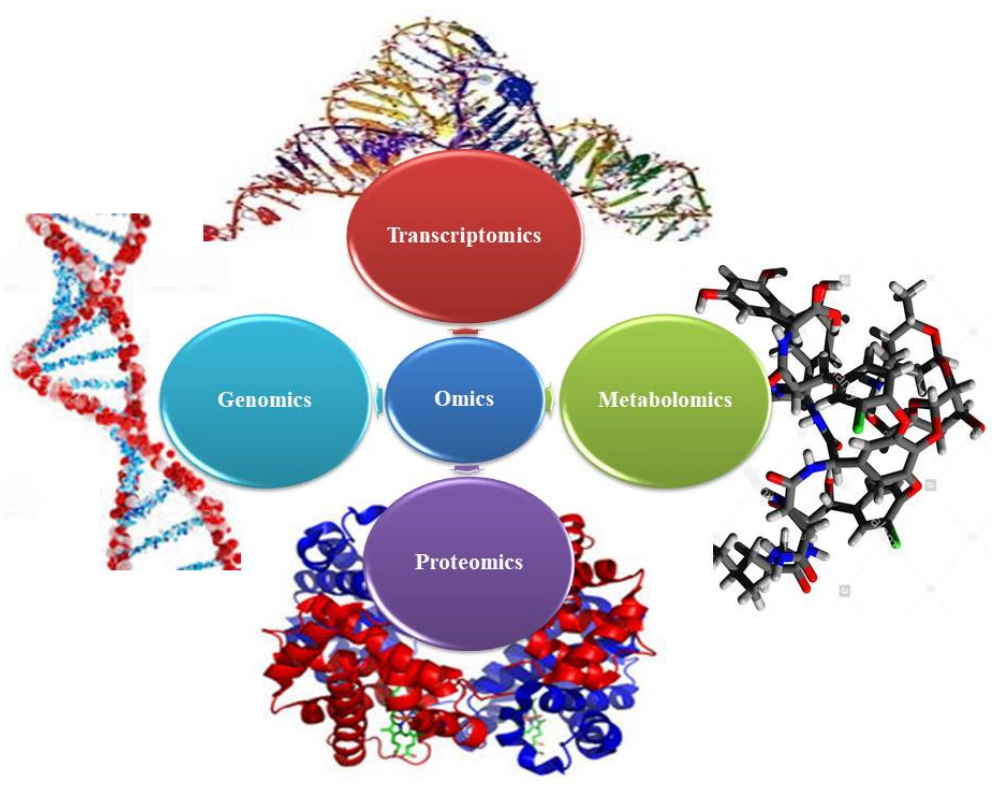

Figure 1. Omics in Medicinal Plants.

\section{Genomics in Medicinal Plants}

The DNA sequences of a genome integrate vital information of the origin, development and epigenomic regulation of a plant. This may act as the foundation of decoding genomic and chemical diversity at minute levels [57]. The high-throughput sequencing of various therapeutic plants emphasizes the biosynthetic pathways of their drug molecules, secondary metabolites [58], and regulatory pathways. The genomic sequencing of plants helps us to investigate various genes and regulatory sequences of medicinal importance. Whole-genome sequencing, besides being a costly process, is also demanding when the genome contains a huge share of repetitive sequences, elevated levels of heterozygosity, and non-diploids [59]. The sequenced genome of grapes is available online (http:/ / www.genoscope.cns.fr/spip/ accessed on 17 November 2020) [60,61]. Phalaenopsis equestris (Schauer) Rchb.f [62], Brassica napus L. [63], Capsicum annuum L. [64,65], Momordica charantia L. [66], Coffea canephora Pierre ex A. Froehner [67], Salvia miltiorrhiza Bunge [68], Ziziphus jujuba Mill. [69,70], Glycyrrhiza uralensis Fisch. Ex DC. [71], Dendrobium officinale Kimura et Migo [72], Azadirachta indica A. Juss., 1830 [73], and Catharanthus roseus (L.) G. Don chloroplast and genome $[49,74]$ and the chloroplast of Pogostemon cablin (Blanco) Benth. [75] have been sequenced. These may emerge as significant models for the study of herb genetics and their cell metabolic actions $[49,76]$. Salvia miltiorrhiza Bunge (Danshen) and Catharanthus roseus (L.) G. Don synthesizes triterpenes, indole alkaloids and diterpene quinone. The draft genome sequence of Catharanthus roseus (L.) G. Don offers verification of the partial gene clustering for alkaloid (vinblastine and vincristine) biosynthesis. With bacterial artificial chromosome sequencing, Kellner et al. [49] showed seven small clusters, each one of two to three genes, in the biosynthetic pathways of vinblastine and vincristine. Ziziphus jujuba Mill. is rich in vitamin $C$ and sugar, and has a variety of medicinally essential flavonoids, phenolics and alkaloids. Azadirachta indica A. Juss. is medicinally effective as 
an antitumorigenic, antidiabetic and antimalarial. The genome of neem sequenced with the next generation sequencing approach is loaded with AT sequences and modest repetitive DNA, and has 20,000 genes [77]. The genome-wide identification of Salvia miltiorrhiza Burge (Danshen) and the characterization of its putative genes involved in the terpenoid biosynthetic pathway was studied by Ma et al. [78]. The cp genome draft sequence of Salvia miltiorrhiza Burge (Danshen) [79] verifies its genome size as approximately $600 \mathrm{MB}$, having 30,478 genes that code for protein and 1620 genes that act as transcription factors. Some of these take part in the biosynthetic pathways of tanshinone and phenolic acids, which are useful in the treatment of hyperlipidemia, and cardiovascular and cerebrovascular diseases. In Salvia miltiorrhiza Burge (Danshen), 40 terpenoid biosynthetic pathway genes have been discovered. Among these, 27 genes were new, which comprise 19 families (10 with single and 9 with multigene). In the terpenoid biosynthetic pathway of S. miltiorrhiza Burge (Danshen), HDR, DXS, HMGR and GGPPS enzymes are transcribed by multigene families that have diverse expression profiles and subcellular positions [78]. The domestication and differentiation of Capsicum was undertaken by the comparative genome sequencing of cultivated Capsicum annuum pepper variety Zunla-1 with wild progenitor Capsicum annuum var. glabriusculum (Chiltepin) [64]. The genome sequences of Solanum tuberosum L., Capsicum, Atropa and tomato give information about the evolution of various members of the Solanaceae family. Innumerable anticancerous plant-based chemical molecules, such as camptothecin and podophyllotoxin derivatives [80], can be probed with this strategy. Modern day next generation sequencing of the Panax ginseng cp genome gives an insight into its evolution and polymorphism [81]. Panax ginseng promotes health and is useful in clinical therapy. The genome sequencing of Dendrobium officinale Kimura et Migo, which is a medicinal plant, and the orchid Cypripedium macranthos Sw. provides an insight into the content and order of their genes and latent RNA editing sites [82]. Ocimum sanctum L. and Ocimum basilicum L. genome sequencing and annotation reveals higher expressions of genes of the phenylpropanoid/terpenoid biosynthetic pathway, cytochrome P450s and transcription factors. This has provided a new approach for the mining of biosynthetic pathways of important medicinal metabolites in related species $[83,84]$. The cp genome sequence of Ocimum tenuiflorum L. disclosed that the amino acid mutations at the gene loci of biosynthesis give it incomparable pharmaceutical traits. Ocimum tenuiflorum L. generates specialized metabolites with anticancer potential, such as ursolic acid, oleanolic acid, luteolin, taxol, eugenol, apigenin and sitosterol, as a defense mechanism. The genes responsible for the expression of these metabolites with anticancer potential can be identified and used for the development of targeted drugs [85]. In opium poppy (Papaver somniferum L.), the genes of benzylisoquinoline alkaloid (BIA) biosynthesis have been identified by virus-induced gene silencing (VIGS) technology. This has also helped us to discover the genes of the morphine biosynthetic pathway involved in reactions of O-demethylation with metabolite thebaine to produce codeine and then the conversion of the metabolite codeine into morphine [42,43]. The genomic data from restriction site-associated DNA sequencing (RAD-Seq) [86], which is used to assess the genome heterozygosity, and genotyping by sequencing (GBS) method are employed to establish the origin and distribution blueprint of the plants with anticancer potential [57]. Microsatellite markers assist in the reproduction of plants, the regulation of the genome, recombination, quantitative genetic variation, evaluation and organization, evolution, and the defense of the genetic resources. In the hemi-parasitic plant Viscum coloratum (Kom.) Nakai, with anticancerous properties, 19 new polymorphic microsatellite markers were developed, so that the ecological conservation and population genetics of this plant can be studied [87]. The study of evolutionary genomics helps in identifying genes involved in specific innovations, botanical diversity, as well as medicinally important characteristics, for example, anti-allergic, anticancerous, anti-inflammatory, etc. [57]. ISSR analysis in 32 native populations of an endangered Berberidaceae medicinal plant Sinopodophyllum hexandrum (Royle) Ying showed its genetic diversity and structure of population, and provided data for the studies of evolution and conservation [88]. The genome resources assist in the association of genomic variations with the origin of new 
phytochemicals and physiological traits in the therapeutic plants [89]. To conclude, the genomics of medicinal plants provide information on the genes and regulatory sequences, latent RNA editing sites, origin, evolution, development, domestication, differentiation, polymorphisms, epigenomic regulation, genome heterozygosity, genotyping and biosynthetic pathways of drug molecules, secondary metabolites and their regulatory pathways. However, it is a costly and demanding process in genomes with higher percentages of repetitive sequences and heterozygosity.

\section{Transcriptomics in Medicinal Plants}

The transcriptomes of hundreds of therapeutic plants for instance, Oenothera (Onagraceae) [90], Fabaceae [91], Caryophyllales [92], Polygonum cuspidatum Sieb. et Zucc. [93], Rhodiola algida (Crassulaceae) [94], Taxus mairei [95], Salvia sclarea L. (Lamiaceae) [96], etc., subjected to sequencing are available online at the Sequence Read Archive (SRA), National Centre for Biotechnology Information (NCBI), PubMed and Gene Expression Omnibus (GEO) databases. High-throughput comparative transcriptomics of medicinal plants is more viable in comparison to comparative genomics. Transcriptomics is an efficient approach to retrieve the genomic data from numerous non-model therapeutic plants that lack a reference genome. The transcriptomic studies help in the characterization of key characteristics involved in the formation of secondary metabolites and in probing pharmaceutically important mechanisms at the molecular level [94-97]. With RNA sequencing (RNA-seq), gene sequences can be obtained from plants without a reference genome, and with them integrated analyses of transcriptomics (transcriptome data) and metabolomics (metabolic profiling data sets) potential for any medicinal plant [98]. Whole transcriptome shotgun sequencing (WTSS) makes it possible to probe the genes of various metabolite biosynthesis processes and the relationship between the genes and plant metabolites.

From transcriptome data of Podophyllum hexandrum Royle, candidate genes were selected and combinatorially expressed in Nicotiana benthamiana Domin. This way, six enzymes from the podophyllotoxin biosynthetic pathway to etoposide aglycone were identified [99]. Podophyllotoxin is a natural precursor of etoposide, which is a chemotherapeutic anticancerous molecule. The podophyllotoxin biosynthetic pathway is only partly known [99]. Simultaneous co-expressions of 10 genes in model plant tobacco led to the reconstitution of the biosynthetic pathway into etoposide aglycone. The etoposide aglycone is a natural lignin and mediator precursor of anticancerous etoposide. The olivetolic acid cyclase enzyme, a polyketide synthase and an acyl-activating enzyme that is responsible for the synthesis of olivetolic acid, was identified from the transcriptome data of glandular trichomes of the female flower of cannabis (Cannabis sativa L.) Glandular trichomes of the female flower of cannabis are the primary sites of cannabinoid biosynthesis, suggesting their unnoticed role in the generation of chemical diversity [100,101]. Chlorophytum borivilianum Santapau \& R. R. Fern. has revealed antitumerogenic and anticancerous potential [102] due to chloromaloside-A, spirostanol-pentaglycosides-embracing beta-Dapiofuranose and steroidal glycosides. The medicinal phytometabolites, such as saponins, alkaloids, terpenoids and polysaccharides, some of which are antitumerogenic, have been identified in Ranunculaceae. The expression profiling of various genes and appropriate transcriptomics platforms have revealed the distinct outcomes of phyto-metabolites in cancerous cells [103]. The transcriptomic data of Catharanthus roseus (L.) G. Don generates diverse iridoid-based monoterpene indole alkaloids along with anti-cancerous vinblastine [104]. From these transcriptomic data, a new iridoid synthase was identified that converts 10-oxogeranial into iridoid scaffold [105] and cytochrome P450 hydroxylating genes concerned with the monoterpenoid indole alkaloid biosynthetic pathway [76]. Iridoids possess anti-inflammatory, anticancerous and antibacterial potential $[106,107]$. Curcuma longa L. decreases the prevalence of gastrointestinal cancers due to secondary metabolite Curcumin. Curcuma longa L. (rhizome) transcriptomics showed transcripts associated with the terpenoid biosynthetic pathways and other biosynthetic pathways of various anticancerous phytochemicals, such as vinblastine, curcumin and taxol. This informa- 
tion paved the way for the biosynthetic pathways of a variety of terpenoids in Curcuma longa L., along with its transcriptomic database [108]. Phylotranscriptomic approaches provide knowledge about the evolution of the essential anticancerous traits of a plant attributed to its inestimable chemo diversity [109]. Rubiaceae member, Ophiorrhiza pumila Champ. ex Benth., accrues a monoterpenoid indole alkaloid known as camptothecin, which is an anticancerous metabolite. The deep transcriptome analysis of Ophiorrhiza pumila Champ. ex Benth. yielded a 2GB sequence from which novel genes of plant secondary metabolic biosynthetic pathways were predicted [98]. Withania somnifera (L.) Dunal synthesizes bioactive secondary metabolites known as withanolides. The leaf and root tissue chemo-profiling of Withania somnifera (L.) Dunal chemovars showed variations in the composition and traits of withanolides. The genes of chemotypes and the tissue-specific biosynthesis of withanolide of distinct chemotypes was characterized [110]. The differential transcriptomics and metabolic profiling of engineered culture cells that do or do not produce camptothecin alkaloids identifies candidate genes of the biosynthesis of alkaloids and anthraquinones $[98,111]$. The combination of transcriptomics and genetic approaches proposes the existence of a complex gene cluster in the genome used for alkaloid noscapine biosynthesis in the chemo-variety of Papaver somniferum L. [44]. Advanced genome sequencing and comparative transcriptomics have advanced our understanding of the functions of diverse genes involved in the biosynthetic pathways. By cDNA microarray from various stages of hairy root development in Salvia miltiorrhiza Burge (Danshen), Cui et al. [112] found variations in the expression profiles of the genes of the tanshinone biosynthetic pathway. From RNA-seq data of Salvia miltiorrhiza Burge (Danshen), a group of novel genes related to terpenoid-derived tanshinone and salvianolic acid secondary metabolite biosynthesis was identified [113]. In the five key secondary metabolic biosynthetic pathways that cover almost all bases in the phenylpropanoid and terpenoid pathways, the identification of 1539 unigenes was possible. The functional characteristics of approximately 70 new transcripts of phenylpropanoid and terpenoid biosynthetic pathways and the spatiotemporal expression profiles of 10 novel transcripts correlated to terpenoid and phenolic acid biosynthetic pathways were understood through the transcriptome. The differential gene expression profiling of Lupinus angustifolius L. chemo-varieties for quinolizidine alkaloids, the gene that encodes the enzyme lysine decarboxylase involved in the first step of the alkaloid biosynthetic pathway, was undertaken, and the catalytic potential of the lysine decarboxylase was explained by site-directed mutagenesis and protein modeling [114]. The putative homologue genes of the iridoid biosynthetic pathway were identified from the transcriptome of a variety of TIA-producing therapeutic plants [115]. Then, they were evaluated with non-secologaninous plants to remove unrelated genes, and the authors validated the necessity of CrDL7H- 7-deoxyloganic acid 7-hydroxylase (CYP72A224) in iridoid metabolism and its homologous nature with the secologanin synthase-like gene of Camptotheca acuminata Decne. [116]. RNA-seq gives rich sequence information about the full-length gene sequences, and also helped recognize the orthologous and paralogous gene cluster families in Camptotheca acuminata Decne., Rauvolfia serpentina (L.) Benth. ex Kurz and Catharanthus roseus (L.) G. Don for the respective biosynthesis of camptothecin, ajmaline and vinblastine [115,117]. In 2012, Gongora-Castillo and coworkers developed a transcriptomics database. From this database, the alcohol dehydrogenase homologue known as the tetrahydroalstonine synthase (THAS) gene, which was upregulated by MeJA and converts strictosidine aglycone into tetrahydro-alstonine, was validated via VIGS, nuclear magnetic resonance (NMR) imaging and liquid chromatography-mass spectrometry (LC-MS) [118]. The RNA-seq of two Vaccinium macrocarpon Aiton (Cranberry) fruits at different developmental stages was annotated from public domains such as NCBI, KEGG, $\mathrm{GO}$ and $\mathrm{NT}$, and the genes $\mathrm{CHS}, \mathrm{FH}, \mathrm{CHI}, \mathrm{F3}{ }^{\prime} \mathrm{H}$, and $\mathrm{LDOX}$ of the bioactive flavonoid biosynthetic pathway were identified [101]. The cranberry transcriptome, in comparison to blueberry (Vaccinium sp.), reveals a UDP-glucose flavonoid 3-O-glucosyl transferase (UFGT) enzyme of the flavonoid biosynthetic pathway, which characterizes more different types of flavonoids that are accessible in the cranberry transcriptome. Further, the ABC transporters 
and glutathione S-transferases (GST), WD40, WRKY and bHLH regulatory transcription factors, involved in flavonoid biosynthesis were also found in this transcriptome [119]. The metabolic changes that take place in the fruit-ripening of Rubus coreanus Miq. 1867 (rich in anthocyanins) were assessed by metabolomics and transcriptomics [120]. From the data of transcriptome, the annotated unigenes of flavonoid metabolism, along with main genes such as $\mathrm{F} 3 \mathrm{H}, \mathrm{CHS}$ and $\mathrm{CHI}$, were identified. In rice, tomato and petunia, the $\mathrm{CHI}$ gene is the chief gene of the flavonoid and anthocyanin biosynthetic pathway [121-123]. The CHI enzyme family was screened from the transcriptome database of Korean black raspberry, and its function was authenticated by complementary tests in Arabidopsis transparent testa 5-1 (tt5-1) mutant, which is devoid of CHI potential. Comparative transcriptomics of two strains of Magnolia sprengeri Pampanini, and Nuovo Giorn with red and white flowers, revealed some key enzymes of the flavonoid biosynthetic pathway, such as phenylalanine ammonia-lyase, cinnamate-4-hydroxylase, $F 3^{\prime} H, F 3 H$ and $C H S$. The families of $M Y B, b H L H$ and WD40 transcription factors also regulate the anthocyanidin metabolic pathway. With FPKM investigation, eight of these genes for transcription factors associated with the transcript abundance of genes, metabolic processes, and the color of flowers showed an eightfold boost in expression level in Magnolia sprengeri Pampanini, and Nuovo Giorn red-flowered strain, compared to the white-flowered strain [124]. In Chlorophytum borivilianum Santapau \& R.R.Fern., which is an endangered species, an adaptogen, antiaging agent and promoter of general health, the transcriptome analysis enabled insights into the molecular mechanism of flavonoid glycosylation [125]. Transcriptome analysis in different stages of grapefruit ripening was done and the gene expression profiling was clustered by K-means grouping of RPKM [126]. To conclude, the transcriptomics of medicinal plants provided information on the relationship between genes and plant metabolites, the expression profiling of genes, key characteristics, and the molecular bases of secondary metabolite formation and biosynthetic pathways, such as iridoid, flavonoid, terpenoid, podophyllotoxin, terpenoid-derived tanshinone and the salvianolic acid secondary metabolite pathway. Transcriptomics is more viable than comparative genomics. The details of the medicinal plants reviewed are given in Table 1.

\section{Proteomics and Functional Analysis of Proteins in Medicinal Plants}

The field of proteomics is a potent platform to investigate comprehensively the proteins regulated by the drugs and explore signaling pathways of cell perturbations. Proteomics has a range of functions in medicinal plant research. Proteomics illustrates the structures, functions and modifications of proteins, and the protein-protein interactions taking place under in vitro and in vivo conditions [127]. The authentication of post-translational modifications, such as protein phosphorylation, protein acetylation, protein glycosylation and proteolysis, can also be performed [128]. These protein modifications arise during disease progression or after the treatment of a disease with drugs, or even naturally under controlled conditions. The mechanism of action of drugs is examined by the macro-investigation of alterations in proteins and by the detection of proteins that undergo modification as potential targets of the drugs [127]. The multifunctional field of proteomics helps in the prediction of the protein targets of plant-based bioactive compounds, and also provides a logical approach to appreciating the mechanisms of traditional Chinese medicine (TCM) in tumor cells and protein-drug interactions at the molecular level [129]. Terpenoids, flavonoids, glycosides and other secondary metabolites identified from TCM plants have antitumor potential in various cancers, as studied extensively via proteomics. The natural plant drug molecules cause the suppression of tumors by completely targeting the mitochondria present in the cells of malignant tissue [129]. Luteolin, Baicalein, and Tangeretin, which are the natural flavones, show signs of anticancerous activity; however, their mode of action is ambiguous. The baicalein up-regulates peroxiredoxin-6, causing reductions in reactive oxygen species (ROS) generation and hindrances in the cell proliferation of colorectal cancer [130]. The natural flavone Luteolin shows analogous anticancerous potential against various categories of cancers, together with hepatic cancer in humans. 
Tripterygium wilfordii Hook. f. has been extensively and effectively utilized for the treatment of several human syndromes, for instance rheumatoid (RH) arthritis and skin psoriasis. The anticancerous value and intrinsic mechanisms of action of Tripterygium wilfordii Hook. F. have been examined, and at the proteomic level the effect of a bioactive metabolite diterpenoid epoxide triptolide in curing colon cancer has been demonstrated [131]. The metabolite triptolide stimulates division at the cellular level, and a key protein 14-3-3 , involved in the arrest of the cell cycle and the death of cells, undergoes perinuclear translocation [132]. Andrographis paniculata (Burm. F) also contains diterpene compounds that have medicinal applicability against various human disorders, such as cancer and hepatitis, and viral and pathogenic bacteria [133]. Proteomic study is a proficient method for achieving a complex understanding of the inheritable traits and the physiological status of plant members of the family Acanthaceae [134]. Periplocin is extracted from the tissues of the bark and stems of Periploca graeca L., and can help fight cancers in the lungs and colon both in the laboratory and under natural conditions via the beta-catenin/TCF signaling pathway, by means of inducing apoptosis. With tandem mass spectrometry (TMS) and 2D gel electrophoresis, the outcome of periplocin's action on the cell line A549 of lung cancer was studied. Western blot analysis validated and investigated the proteins subjected to modifications and protein-protein interactions [135]. Curcumin from Curcuma longa L. has antioxidant, antineoplastic, anti-angiogenic and anticancerous value. With proteomics, the activity of curcumin in diverse cancerous cell lines was confirmed. The proteomic investigation differentiated twelve proteins with differential expression patterns that enhance functions such as transcription, glycolysis, RNA translation, the splicing of mRNA and lipid metabolism, the synthesis of proteins, protein folding and the degradation of proteins, amino acid synthesis, and the motility of cells in the MCF-7 cell line of human breast cancer [136]. The proteins undergo differential expression in HepG2 liver cancerous cells upon treatment with Berberine. Berberine is isolated from Coptis chinensis Franch., and its anti-proliferative properties lead to the arrest of the cell cycle at the G0 stage of mitosis and the apoptosis of cells [137]. Gambogic acid, which is a natural xanthonoid molecule, is isolated from Garcinia hanburyi Hook. f. resin. It has revealed promising antitumor activity in clinical trials and hinders the growth of a range of cancer cells through multiple signaling pathways [138-140]. In hepatocellular carcinoma, gambogic acid possibly targets Stathmin. Over eighty anticancerous metabolites were predicted to appear in species of Garcinia. Garcinia oblongifolia Champ. ex Benth contains the bioactive metabolite 1, 3, 6, 7-tetrahydroxyxanthone that restricts cell proliferation in hepatocellular cancerous cells via

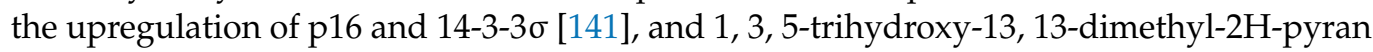
[7, 6-b] xanthone can stimulate the death of cancerous cell by the suppression of Heat Shock Protein 27 [142], which plays a crucial role. From the roots of Salvia miltiorrhiza Burge (Danshen), Tanshione IIA, which is phenanthrene quinine, is extracted. Tanshione IIA also down-regulates Heat Shock Protein 27 expression in cervical cancerous cells [127]. In another study in 2014, the treatment of primary T cell lymphoma in the central nervous system with fenugreek seeds showed an incidence of tumor regression by cancer cell destruction through cytotoxins [143].

In Catharanthus roseus (L.) G. Don, the systematic analysis of the proteome was undertaken via 2D polyacrylamide gel electrophoresis. Mass spectrometry identified proteins such as strictosidine synthase and tryptophan synthase, involved in alkaloid biosynthetic pathway [144]. Differential proteomic analyses of leaves, flowers, and glands of Cannabis sativa L. with different levels of cannabinoids were performed by two-dimensional gel electrophoresis (2D-gel), followed by mass spectrometry. The counting of resolved gel spots on 2D-gel indicated the presence of at least 800 proteins in leaves and flowers. Less than 100 proteins expressed in the flowers were characterized by mass spectrometry [145]. The first comprehensive draft map of the Cannabis proteome has given evidence for the expression of over 17,269 protein-coding regions [146]. Global proteomic profiling of the Artemisia annua L., and quantitative targeted sub-proteomic analysis of two chemotypes of high (HAP) and low (LAP) artemisinin content enabled identification of 13403 proteins on 
the basis of the genome sequence annotation database, and 182 proteins on the basis of mass spectrometry, respectively [147]. MS-based proteomics of the trichome shed light on the trichome machinery in Artemisia annua L. and its role in the production of artemisinin [148]. Kim et al. [149] reviewed in detail the proteomics of the Panax species with the medicinal properties of anticancer, antiaging, and protection against circulatory shock, and performed comparative proteomics of root and leaf tissues of Oriental, American and Indian ginsengs. Proteomics-based knowledge provides insights into ginseng biology. Indian ginseng (Withania sominifera (L.) Dunal) has major secondary metabolites of withanolides. When resolved on the 2D-gels, Indian ginseng root tissue showed 56 unique spots, whereas 22 proteins were identified by MALDI-TOF/TOF [150].

To conclude, the proteomics of medicinal plants provided information on the structure, function and post-translational modifications of proteins, protein-protein interactions, protein targets of plant-based bioactive drugs, protein-drug interactions at the molecular level, and the signaling pathways of cell perturbations. This provides insights into the mechanisms of plant-based medicines in tumor cells and complex understanding of the inheritable traits and physiological status of plant. Proteins undergo post-transcriptional and post-translational modifications. Thus, proteomics data do not always complement transcriptomics data. Therefore, future efforts require integrated omics approaches to explore the biology of any medicinal plant [149].

Table 1. Omics of Medicinal Plants Reported in Review.

\begin{tabular}{|c|c|}
\hline Medicinal Plants & Reference/s \\
\hline \multicolumn{2}{|l|}{ Genomics } \\
\hline Grapes & {$[56,57]$} \\
\hline Phalaenopsis equestris (Schauer) Rchb.f & [58] \\
\hline Brassica napus L. & [59] \\
\hline Capsicum annuum $\mathrm{L}$. & {$[60,61]$} \\
\hline Momordica charantia L. & [62] \\
\hline Coffea canephora Pierre ex A. Froehner & {$[63,74,75]$} \\
\hline Salvia miltiorrhiza Bunge & [64] \\
\hline Ziziphus jujuba Mill. & {$[65,66]$} \\
\hline Glycyrrhiza uralensis Fisch. ex DC. & [67] \\
\hline Dendrobium officinale Kimura et Migo & [68] \\
\hline Azadirachta indica A. Juss., 1830 & [69] \\
\hline Catharanthus roseus (L.) G.Don & {$[45,70,72]$} \\
\hline Pogostemon cablin (Blanco) Benth. & [71] \\
\hline Solanum tuberosum L. & [76] \\
\hline Panax ginseng & [77] \\
\hline Dendrobium officinale Kimura et Migo & [78] \\
\hline Cypripedium macranthos Sw. (1800) & [78] \\
\hline Ocimum sanctum $\mathrm{L}$. & [79] \\
\hline Ocimum basilicum L. & [80] \\
\hline Papaver somniferum L. & {$[42,43]$} \\
\hline Viscum coloratum (Kom.) Nakai & [83] \\
\hline Sinopodophyllum hexandrum (Royle) Ying & {$[84]$} \\
\hline \multicolumn{2}{|l|}{ Transcriptomics } \\
\hline Podophyllum hexandrum Royle & [95] \\
\hline Cannabis sativa $\mathrm{L}$. & {$[96,97]$} \\
\hline Chlorophytum borivilianum Santapau \& R.R.Fern. & {$[98,121]$} \\
\hline Catharanthus roseus (L.) G. Don & {$[100,101,113]$} \\
\hline Curcuma longa L. & [104] \\
\hline Ophiorrhiza pumila Champ. ex Benth. & [94] \\
\hline Withania somnifera (L.) Dunal & [106] \\
\hline Papaver somniferum $\mathrm{L}$. & {$[44]$} \\
\hline Salvia miltiorrhiza Burge (Danshen) & [109] \\
\hline Lupinus angustifolius L. & [110] \\
\hline Camptotheca acuminata Decne. & [112] \\
\hline Rauvolfia serpentina (L.) Benth. ex Kurz & [111] \\
\hline Vaccinium macrocarpon Aiton 1789 & [101] \\
\hline Blueberry (Vaccinium sp.) & [115] \\
\hline Rubus coreanus Miq. 1867 & [116] \\
\hline Magnolia sprengeri Pampanini, Nuovo Giorn & [120] \\
\hline Grapefruit & [122] \\
\hline
\end{tabular}


Table 1. Cont.

\begin{tabular}{|c|c|}
\hline Medicinal Plants & Reference/s \\
\hline \multicolumn{2}{|c|}{ Proteomics } \\
\hline Tripterygium wilfordii Hook.f. & [127] \\
\hline Andrographis paniculata (Burm. F) & [129] \\
\hline Periploca graeca L. & [131] \\
\hline Curcuma longa $\mathrm{L}$. & [132] \\
\hline Coptis chinensis Franch. & [133] \\
\hline Garcinia hanburyi Hook. f. & [134-136] \\
\hline Garcinia oblongifolia Champ. ex Benth & {$[137,138]$} \\
\hline Salvia miltiorrhiza Burge (Danshen) & [123] \\
\hline Catharanthus roseus (L.) G. Don & {$[140]$} \\
\hline Cannabis sativa $\mathrm{L}$. & {$[141,142]$} \\
\hline Artemisia annua L. & {$[143,144]$} \\
\hline Withania sominifera (L.) Dunal & {$[146]$} \\
\hline \multicolumn{2}{|c|}{ Metabolomics } \\
\hline Aloe vera (L.) Burm.f. & [151] \\
\hline Panax ginseng C.A. Mey., & [152] \\
\hline Panax notoginseng (Burkill) F.H.Chen & {$[152]$} \\
\hline Panax japonicus (T.Nees) C.A. Mey & {$[152]$} \\
\hline Persicaria minor (Huds.) Opiz & {$[153,154]$} \\
\hline Artemisia & [155] \\
\hline Pulcaria crispa (Forssk.) Benth. ex Oliv. & [155] \\
\hline Rubus coreanus Miq. 1867 & [116] \\
\hline
\end{tabular}

\section{Metabolomics in Medicinal Plants}

Metabolomics is mainly significant in the plant kingdom, because of the huge quantity of metabolites (primary and secondary) produced by plants [156]. Metabolomics is a potent tool for discovering new chemical entities (NCEs) for the detection and development of drugs, by helping in the discovery and profiling of secondary metabolites in therapeutic plants, the regulation of the response of drugs, and the scrutiny of possible cytotoxic effects. High-throughput screening for the assessment of plant drugs and the detection of biomarkers for revealing human ailments [53,157], the isolation and detection of metabolites, and the fingerprinting of plant metabolites are required for the improved exploitation of therapeutic plants [158]. The metabolomics of the therapeutic plants represents a promising scientific area that assists in the detection of various drug molecules [158-160]. Metabolomics is used in an extensive array together with synthetic biology, medical science and Ayurveda, and is useful in predictive plant system modeling. Secondary metabolites with low therapeutic value and concentrations are not easily detected in plants. Yet, synergistic biological activities are generated due to numerous intrinsic ingredients in plants and herbal formulations. Here, metabolomics operates as a proficient approach to understand the phytochemistry of a range of medicinally active herbal ingredients [158]. The genes involved in some biosynthetic pathways formulate gene clusters in the plant genome [42,161], making gene identification easier, and this also gives an additional exhaustive approach to understanding the specialized metabolites ${ }^{\prime}$ evolution and their function. About 1 million metabolites exist in the whole flora [162], out of which only a few have been investigated for their metabolite biological activities and chemical constituents [163]. This has paved the way for further investigations into the classification of the metabolites of plant species that are as yet unexplored. Approximately 200,000 secondary metabolites have been investigated in plant species, several of which arose from the genome duplications that further caused the fast progression of complex characters $[151,152]$. The three key classes of secondary metabolites of plants, based on their structural characteristics and biosynthetic pathways, are terpenoids $(\sim 36,000)$ (Buckingham, 2007), alkaloids ( 12,000) [153] and phenolics $(\sim 10,000)$ [154].

Metabolomics studies undertaken with the analytical technique of nuclear magnetic resonance spectroscopy are useful for compiling metadata in two diverse dimensions for the detection of any alterations [159]. The methods of NMR spectroscopy and multivariate investigation were utilized to assess the metabolite profile and inhibitory effects in Aloe 
vera (L.) Burm. f., an anticancer and antitumorigenic plant. The metabolome influences the genome of hepatocellular carcinoma cells by escalating the gene expressions of p53 and Bcl-2 [164]. The metabolomic characterization of Panax ginseng C. A. Mey., Panax notoginseng (Burkill) F. H. Chen and Panax japonicus (T. Nees) C.A.Mey. by the UPLCQTOF-MS technique identified secondary metabolites such as chikusetsu saponin IVa and ginsenosides (Rb1, Rb2, Rc, Rg2, R0) [165]. In Persicaria minor (Huds.) Opiz syn. Polygonum minus Huds, 48 compounds with via GC $\times$ GCTOF MS, 42 compounds via GCMS, 37 volatile compounds via GC-MS investigation, and 85 flavonoids via LC-TOF were successfully identified $[155,166]$. Over $50 \%$ of anticancer drugs used in therapeutics today have a natural source $[167,168]$. The profiling of metabolites and the antitumor potential of broadly cultivated plants belonging to Compositae are reported. These species of plants portray changeable metabolite profiles. The plant Artemisia has the maximum secondary metabolite concentration, while Pulcaria crispa (Forssk.) Benth. ex Oliv. shows proficient in- vitro anticancerous action [169]. Mass spectrometry (MS) showed enhancement in the flavonoid and anthocyanin groups and reductions in the sucrose, fatty acids, organic acids and amino acids in Rubus coreanus Miq. [120]. Several therapeutically important plant metabolites, along with their medicinal properties and chemical structures, are given in Table 2. To conclude, metabolomics of medicinal plants provided information on the isolation and detection of metabolites and new chemical entities (NCEs) for the development of drugs, the fingerprinting of plant metabolites, and phytochemistry.

Table 2. Medicinal Properties and Chemical Structures of Some Metabolically Bioactive Compounds from Medicinal Plant Species. (Chemical Structures were Drawn with ChemSpider Software).

\begin{tabular}{|c|c|c|c|c|c|}
\hline Medicinal Plants & $\begin{array}{l}\text { Medicinal } \\
\text { Metabolites }\end{array}$ & $\begin{array}{c}\text { Drugs/Synthetic } \\
\text { Derivatives }\end{array}$ & $\begin{array}{l}\text { Medicinal } \\
\text { Properties }\end{array}$ & Structures & Reference/s \\
\hline Ammi visnaga & $\begin{array}{l}\text { Visnadin, visnagin, } \\
\text { and khellin }\end{array}$ & $\begin{array}{l}\text { Amiodarone for } \\
\text { cardiac dysrhythmias; } \\
\text { Cromolyn for } \\
\text { treatment of asthma }\end{array}$ & $\begin{array}{l}\text { Kidney stones, } \\
\text { menstrual cramps to } \\
\text { atherosclerosis. } \\
\text { Cardiac arrhythmias, } \\
\text { congestive heart } \\
\text { failure, angina, and } \\
\text { hypercholes- } \\
\text { terolemia }\end{array}$ & Khellin & [170-172] \\
\hline $\begin{array}{c}\text { Andrographis } \\
\text { paniculata (Burm.f.) } \\
\text { Nees }\end{array}$ & Andrographolide & $\begin{array}{l}\text { Anti-inflammatory, } \\
\text { antibacterial, } \\
\text { antitumor, } \\
\text { antidiabetic, } \\
\text { antimalarial and } \\
\text { hepatoprotective }\end{array}$ & & & [173] \\
\hline Apium graveolens L. & $\begin{array}{l}\text { L-3-n-butylphthalide } \\
\text { drug }\end{array}$ & & $\begin{array}{l}\text { Promising candidate } \\
\text { for treatment of } \\
\text { cerebral ischemia, } \\
\text { Parkinson's and } \\
\text { Alzheimer's disease }\end{array}$ & & [174] \\
\hline Artemisia annua L. & Artemisinin & $\begin{array}{l}\text { Artemether, } \\
\text { artemether and } \\
\text { artesunate }\end{array}$ & $\begin{array}{l}\text { Antimalarial and } \\
\text { antiviral activity and } \\
\text { resist infections from } \\
\text { protozoans }\end{array}$ & & [175] \\
\hline
\end{tabular}


Table 2. Cont.

\begin{tabular}{|c|c|c|c|c|c|}
\hline Medicinal Plants & $\begin{array}{l}\text { Medicinal } \\
\text { Metabolites }\end{array}$ & $\begin{array}{l}\text { Drugs/Synthetic } \\
\text { Derivatives }\end{array}$ & Medicinal Properties & Structures & Reference/s \\
\hline $\begin{array}{l}\text { Atropa belladonna, } \\
\text { Datura stramonium }\end{array}$ & $\begin{array}{l}\text { Atropine/Hyoscyamine/ } \\
\text { Scopolamine }\end{array}$ & Donnatal & $\begin{array}{l}\text { peripheral anticholinergic } \\
\text { or antispasmodic action }\end{array}$ & & [176] \\
\hline Bacopa monniera L. & $\begin{array}{l}\text { Bacoside A3, } \\
\text { bacopaside 1, } \\
\text { bacopaside 2, } \\
\text { jujubogenin, } \\
\text { bacosaponine C }\end{array}$ & & $\begin{array}{c}\text { Neuromedicine for various } \\
\text { disorders such as anxiety, } \\
\text { depression and memory } \\
\text { loss }\end{array}$ & & [177] \\
\hline $\begin{array}{c}\text { Camptotheca } \\
\text { acuminata Descne } \\
\text { and Nothapodytes } \\
\text { nimmoniana (J. } \\
\text { Grah.) D.J. } \\
\text { Mabberley }\end{array}$ & Camptothecin & $\begin{array}{l}\text { Topotecan and } \\
\text { irinotecan }\end{array}$ & Anticancer & & [178] \\
\hline
\end{tabular}

Cannabis sativa L. Cannabinoids

Catharanthus roseus L.

Vinblastine and vincristine
Anticancer drugs

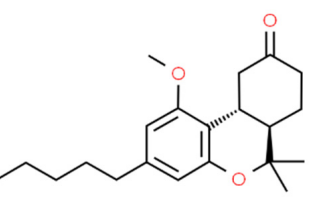

Anti-inflammatory,

muscle relaxant, neuro-antioxidative and

psychoactive drugs

Topical analgesic, Neuropeptide-releasing agent selective for primary sensory peripheral neurons

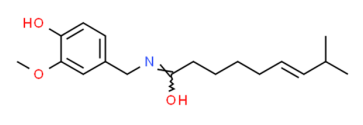

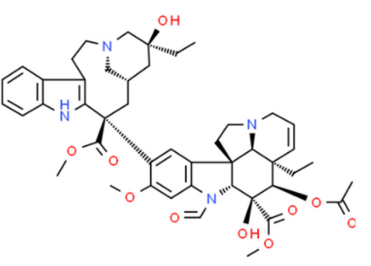

Vincristine

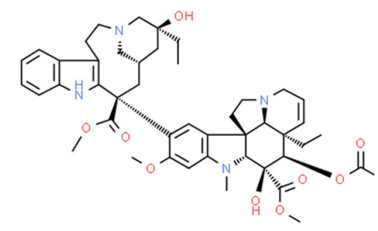

Vinblastine<smiles>C=C[C@@H]1CN2CC[C@@H]1C[C@@H]2[C@H](O)c1ccnc2ccc(OC)cc12</smiles>

[182]
Cinchona officinalis L.
Natural quinine, quinidine
Chloroquine
Antimalaria 
Table 2. Cont.

\begin{tabular}{|c|c|c|c|c|c|}
\hline Medicinal Plants & $\begin{array}{l}\text { Medicinal } \\
\text { Metabolites }\end{array}$ & $\begin{array}{c}\text { Drugs/Synthetic } \\
\text { Derivatives }\end{array}$ & Medicinal Properties & Structures & Reference/s \\
\hline $\begin{array}{l}\text { Picrorhiza kurroa } \\
\text { Royle ex Benth. }\end{array}$ & Picroside & & $\begin{array}{c}\text { Picrosides as } \\
\text { anticarcinogenic agents, } \\
\text { hepatoprotective drug } \\
\text { formulation, picroliv }\end{array}$ & & [195-197] \\
\hline $\begin{array}{l}\text { Podophyllum } \\
\text { hexandrum Royle } \\
\text { (syn. P. emodi } \\
\text { Wall.) and } \\
\text { Podophyllum } \\
\text { peltatum L. }\end{array}$ & Podophyllotoxins & $\begin{array}{l}\text { Etoposide and } \\
\text { teniposide }\end{array}$ & Anticancer drugs & & [198] \\
\hline $\begin{array}{c}\text { Rauwolfia serpentine } \\
\text { L. }\end{array}$ & Reserpine & & Hypertension & & [199] \\
\hline $\begin{array}{l}\text { Salvia miltiorrhiza } \\
\text { Burge (Danshen) }\end{array}$ & $\begin{array}{c}\text { Tanshinoate B, } \\
\text { Danshensu, } \\
\text { Isotanshinone IIA } \\
\text { and } \\
\text { Cryptotanshinone }\end{array}$ & & $\begin{array}{c}\text { Small-molecule } \\
\text { cardiovascular drug } \\
\text { discovery }\end{array}$ & Danshensu & [200] \\
\hline $\begin{array}{c}\text { Taxum brevifolia } \\
\text { Nutt. }\end{array}$ & Taxol & Paclitaxel & & & [201] \\
\hline
\end{tabular}

\section{Conclusions and Future Prospects}

Modern day omics-based technology allows extensive and nano-scale assessments of biological samples for the probing of compounds with medicinal properties. Traditional medicinal plants are very prolific in the discovery of novel plant-based drugs. Medicinal plants have unexploited potential for use in novel molecular target discovery, which adds to the process of drug development. It is imperative to manipulate and investigate not only at the genome level with high-throughput sequencing and recombinant DNA technology, but also at the levels of the proteome with mass spectrometry, the transcriptome with RNA Seq and the metabolome with nuclear magnetic resonance spectroscopy and/or LCMS. In modern day biology, big data is derived from omics technologies, which allow the discovery of unidentified metabolic pathways/enzymes, metabolites, genes, gene networks, and protein-protein interactions, because of which interdisciplinary research on medicinal plant genomics accompanied by high-throughput sequencing platforms for DNA and RNA metabolomics and proteomics is entirely essential. These studies will continue to disclose novel secondary metabolites that are biologically active and thus make the immense 
biological diversity of plants applicable for use in for novel drug discovery. The systems biology tool will help in identifying networks by which pharmacological substances of individual medicinal herbs or synergistic action networks of herbal prescriptions can be resolved and their target signaling pathway networks can be studied. However, the databases, computational models and infrastructure required to pool the disciplines are in their infancy. Systems biology will prove to be a revolutionary research area in plant-based drug discovery and diseases in future.

Author Contributions: D.P., A.P., S.H.W., S.A.M.A., H.A.A., A.M.M.A., M.A.A.-Y., F.A.A.-M., and H.O.E. substantially contributed to the conceptualization and interpretation of data for the work; D.P., A.P., S.H.W., S.A.M.A., H.A.A., A.M.M.A., M.A.A.-Y., F.A.A.-M., and H.O.E. substantially contributed to data curation and drafting of the work; D.P., A.P., S.H.W., S.A.M.A., H.A.A., A.M.M.A., M.A.A.-Y., F.A.A.-M., and H.O.E. substantially contributed to formal analysis; S.A.M.A., H.A.A., A.M.M.A., and H.O.E. contributed to funding acquisition; D.P., A.P., S.H.W., S.A.M.A., H.A.A., A.M.M.A., M.A.A.-Y., F.A.A.-M., and H.O.E. substantially contributed to the investigation; D.P., A.P., S.H.W., S.A.M.A., H.A.A., A.M.M.A., M.A.A.-Y., F.A.A.-M., and H.O.E. substantially contributed to the methodology; D.P., A.P., S.H.W., S.A.M.A., H.A.A., A.M.M.A., M.A.A.-Y., F.A.A.-M., and H.O.E. contributed to the project administration; D.P., A.P., S.H.W., S.A.M.A., H.A.A., A.M.M.A., M.A.A.-Y., F.A.A.-M., and H.O.E. contributed to validation; D.P., A.P., S.H.W., S.A.M.A., H.A.A., A.M.M.A., M.A.A.-Y., F.A.A.M., and H.O.E. contributed to the visualization; D.P., A.P., S.H.W., S.A.M.A., H.A.A., A.M.M.A., M.A.A.-Y., F.A.A.-M., and H.O.E. substantially contributed to writing-original draft; D.P., A.P., S.H.W., S.A.M.A., H.A.A., A.M.M.A., M.A.A.-Y., F.A.A.-M., and H.O.E. substantially contributed to writing-review and editing. All authors approved the final version of the review article to be published. All authors agreed to be accountable for all aspects of the work in ensuring that questions related to the accuracy or integrity of any part of the work are appropriately investigated and resolved, as well as in the design, drafting, analyses, data interpretation, writing, editing, preparing and approving of the final version of the paper. All authors read and approved the final version of the manuscript.

Funding: This research was funded by the Deanship of Scientific Research at Princess Nourah bint Abdulrahman University through the Fast-track Research Funding Program to support publication in the top journal (Grant no. 42-FTTJ-05).

Institutional Review Board Statement: Not applicable.

Informed Consent Statement: Not applicable.

Acknowledgments: This research was funded by the Deanship of Scientific Research at Princess Nourah bint Abdulrahman University through the Fast-track Research Funding Program to support publication in the top journal (Grant no. 42-FTTJ-05).

Conflicts of Interest: The authors declare no conflict of interest.

\section{References}

1. Costion, C.; Ford, A.; Cross, H.; Crayn, D.; Harrington, M.; Lowe, A. Plant DNA barcodes can accurately estimate species richness in poorly known floras. PLoS ONE 2011, 6, e26841. [CrossRef] [PubMed]

2. Jiao, Y.; Wickett, N.J.; Ayyampalayam, S.; Chanderbali, A.S.; Landherr, L.; Ralph, P.E.; Tomsho, L.P.; Hu, Y.; Liang, H.; Soltis, P.S.; et al. Ancestral polyploidy in seed plants and angiosperms. Nature 2011, 473, 97-100. [CrossRef] [PubMed]

3. Chen, S.; Song, J.; Sun, C.; Xu, J.; Zhu, Y.; Verpoorte, R.; Fan, T.P. Herbal genomics: Examining the biology of traditional medicines. Science 2015, 347, 527-529.

4. Pandita, D.; Pandita, A.; Pandita, S. Is “The Doctrine of Signatures" Signature Sequences Designed by God? Int. J. Sci. Res. 2016, 6, 568-572.

5. Payne, G.F.; Bringi, V.; Prince, C.; Shuler, M. The quest for Commercial Production of Chemicals from Plant Cell Culture. In Plant Cell and Tissue Culture in Liquid Systems; Payne, G.F., Bringi, V., Prince, C., Shuler, M.L., Eds.; Hanser: Munich, Germmany, 1991; pp. 1-10.

6. Cámara-Leret, R.; Faurby, S.; Macía, M.J.; Balslev, H.; Göldel, B.; Svenning, J.C.; Kissling, W.D.; Rønsted, N.; Saslis-Lagoudakis, C.H. Fundamental species traits explain provisioning services of tropical American palms. Nat. Plants 2017, 3, 16220. [CrossRef] [PubMed]

7. Nilsson, K.; Sangster, M.; Konijnendijk, C.C. Forests, Trees and Human Health and Well-being: Introduction. In Forests, Trees and Human Health; Nilsson, K., Ed.; Springer: Dordrecht, The Netherlands, 2011. [CrossRef] 
8. Brusotti, G.; Cesari, I.; Dentamaro, A.; Caccialanza, G.; Massolini, G. Isolation and characterization of bioactive compounds from plant resources: The role of analysis in the ethnopharmacological approach. J. Pharm. Biomed. 2014, 87, 218-228. [CrossRef]

9. Briskin, D.P. Medicinal plants and phytomedicines. Linking plant biochemistry and physiology to human health. Plant Physiol. 2000, 124, 507-514. [CrossRef]

10. Suárez, A.I.; Chávez, K. Appraisal of medicinal plants with anticancer properties in South America. In Anticancer Plants: Properties and Application; Akhtar, M.S., Swamy, M.K., Eds.; Springer: Singapore, 2018; Volume 1, pp. 229-283.

11. Busia, K.; Kasilo, O.M. Overview of traditional medicine in Ecowas Member States. Afr. Health Monit. 2010, 13, 16-24.

12. Nikolovski, B. Arab pharmacy in Macedonia. Bulletin 1961, 1, $20-27$.

13. Katic, R. The Chilandar Medical Codex N. 517; Milincevic, V., Ed.; National Library from Serbia: Belgrade, Serbia, 1980 ; pp. 9-80.

14. Katic, R. The Serbian Medicine from 9th to 19th Centuries; Scientific Work: Belgrade, Serbia, 1967; pp. $22-37$.

15. Schmitz, R. Friedrich Wilhelm Sertürner and the discovery of morphine. Pharm. Hist. 1985, 27, 61-74.

16. Joshi, K.; Ghodke, Y.; Shintre, P. Traditional medicine and genomics. J. Ayurveda Integr. Med. 2010, 1, 26-32. [CrossRef] [PubMed]

17. Modak, M.; Dixit, P.; Londhe, J.; Ghaskadbi, S.; Devasagayam, T.P.A. Indian herbs and herbal drugs used for the treatment of diabetes. J. Clin. Biochem. Nutr. 2007, 40, 163-173. [CrossRef] [PubMed]

18. World Health Organization. Quality Control Methods for Medicinal Plants Materials; WHO: Geneva, Switzerland, 2005; Available online: http:/ / apps.who.int/medicinedocs/pdf/s7918,e/s7918,e.pdf (accessed on 24 December 2015).

19. Kaushal, N.; Rao, S.; Ghanghas, P.; Abraham, S.; George, T.; D’Souza, S.; Mathew, J.M.; Chavali, J.; Swamy, M.K.; Baliga, M.S. Usefulness of Ocimum sanctum Linn. in cancer prevention: An update. In Anticancer Plants: Properties and Application; Akhtar, M.S., Swamy, M.K., Eds.; Springer: Singapore, 2018; Volume 1, pp. 415-429.

20. Farnsworth, N.R. Screening Plants for New Medicines. In Biodiversity; Wilson, E.O., Ed.; National Academy Press: Washington, DC, USA, 1988; pp. 83-97.

21. Chen, S.L.; Yu, H.; Luo, H.M.; Wu, Q.; Li, C.F.; Steinmetz, A. Conservation and sustainable use of medicinal plants: Problems, progress, and prospects. Chin. Med. 2016, 11, 37. [CrossRef]

22. Kumar, V.V.; Swamy, M.K.; Akhtar, M.S. Anticancer Plants and their Conservation Strategies: An Update. In Anticancer Plants: Properties and Application; Akhtar, M.S., Swamy, M.K., Eds.; Springer: Singapore, 2018; Volume 1, pp. 455-483.

23. Bandaranayake, W.M. Quality control, screening, toxicity and regulation of herbal drugs. In Modern Phytomedicine: Turning Medicinal Plants Into Drugs; Iqbal, A., Farrukh, A., Eds.; Wiley: New Jersey, NJ, USA, 2006; pp. 25-57.

24. DeLuca, V.; Salim, V.; Atsumi, S.M.; Yu, F. Mining the biodiversity of plants: A revolution in the making. Science 2012, 336, 1658-1661. [CrossRef] [PubMed]

25. GIA: Global Industry Analysts (GIA), Inc. Report on the Global Herbal Supplements and Remedies Market Trends Drivers \& Projections. Available online: http://www.strategyr.com/marketresearch/herbalsupplementsandremediesmarkettrends.asp (accessed on 15 February 2015).

26. Aneesh, T.P.; Hisham, M.; Sekhar, M.S.; Manjusree, M.; Deepa, T.V. International market scenario of traditional Indian herbal drugs in India is declining. Int. J. Green Pharm. 2009, 3, 184-190. [CrossRef]

27. Prasad, L.V. Indian System of Medicine and Homoeopathy Traditional Medicine in Asia; Chaudhury, R.R., Rafei, U.M., Eds.; WHORegional Office for South East Asia: New Delhi, India, 2002; pp. 283-286.

28. Biswas, K.; Biswas, R. DNA molecular markers based authentication of herbal drugs-A review. IJPRS 2014, 3, 581-593.

29. Mishra, P.; Kumar, A.; Nagireddy, A.; Mani, D.N.; Shukla, A.K.; Tiwari, R.; Sundaresan, V. DNA barcoding: An efficient tool to overcome authentication challenges in the herbal market. Plant. Biotechnol. 2015, 14, 8-21. [CrossRef]

30. Pandita, D.; Pandita, A.; Pandita, S. The Revitalizing \& Recuperative Higher Tracheophytes of Jammu Province, Jammu and Kashmir (India). Int. J. Indig. Med. Plants 2014, 47, 1603-1620.

31. Pandita, D.; Pandita, A.; Pandita, S. Herbaceous Medicinal \& Therapeutic Plants of District Samba of Jammu Province, Jammu \& Kashmir (India). Int. J. Indig. Med. Plants 2013, 46, 1224-1238.

32. Pandita, D.; Pandita, A.; Pandita, S. Pharmacological and Phytochemical Portrayal of Dicotyledonous Medicinal Plants of Jammu and Kashmir abound with Antidiabetic Potential. J. Microbiol. Biotech. Res. 2015, 5, 16-27.

33. Pandita, D.; Pandita, A.; Pandita, S. Pharmacological and Phytochemical Portrayal of Monocotyledonous Medicinal Plants of Jammu and Kashmir abound with Antidiabetic Potential. J. Microbiol. Biotech. Res. 2015, 5, 28-33.

34. Mehta, A.; Hasija, Y. Bioinformatics Approaches for Genomics and Post Genomics Applications of Anticancer Plants. In Anticancer Plants: Mechanisms and Molecular Interactions; Akhtar, M.S., Swamy, M.K., Eds.; Springer: Singapore, 2018; Volume 4, pp. $283-317$.

35. Chakraborty, P. Herbal genomics as tools for dissecting new metabolic pathways of unexplored medicinal plants and drug discovery. Biochim. Open 2018, 6, 9-16. [CrossRef]

36. Swamy, M.K.; Paramashivaiah, S.; Hiremath, L.; Akhtar, M.S.; Sinniah, U.R. Micropropagation and Conservation of Selected Endangered Anticancer Medicinal Plants from the Western Ghats of India. In Anticancer Plants: Natural Products and Biotechnological Implements; Akhtar, M.S., Swamy, M.K., Eds.; Springer: Singapore, 2018; Volume 2, pp. 481-505.

37. Swamy, M.K.; Sinniah, U.R.; Ghasemzadeh, A. Anticancer potential of rosmarinic acid and its improved production through biotechnological interventions and functional genomics. Appl. Microbiol. Biotechnol. 2018, 102, 7775-7793. [CrossRef] [PubMed]

38. Yonekura-Sakakibara, K.; Fukushima, A.; Saito, K. Transcriptome data modeling for targeted plant metabolic engineering. Curr. Opin. Biotechnol. 2012. [CrossRef] [PubMed] 
39. Hale, V.; Keasling, J.D.; Renninger, N.; Diagana, T.T. Microbially derived artemisinin: A biotechnology solution to the global problem of access to affordable antimalarial drugs. Am. J. Trop. Med. Hyg. 2007, 77 (Suppl. 6), 198-202. [CrossRef] [PubMed]

40. Sumner, L.W.; Lei, Z.; Nikolau, B.J.; Saito, K. Modern plant metabolomics: Advanced natural product gene discoveries, improved technologies, and future prospects. Nat. Prod. Rep. 2015, 32, 212-229. [CrossRef]

41. Suzuki, M.; Nakabayashi, R.; Ogata, Y.; Sakurai, N.; Tokimatsu, T.; Goto, S.; Suzuki, M.; Jasinski, M.; Martinoia, E.; Otagaki, S.; et al. Multiomics in grape berry skin revealed specific induction of the stilbene synthetic pathway by ultraviolet-C irradiation. Plant Physiol. 2015, 168, 47-59. [CrossRef]

42. Hagel, J.M.; Facchini, P.J. Dioxygenases catalyze the Odemethylation steps of morphine biosynthesis in opium poppy. Nat. Chem. Biol. 2010, 6, 273-275. [CrossRef]

43. Gesell, A.; Rolf, M.; Ziegler, J.; Diaz Chavez, M.L.; Huang, F.C.; Kutchan, T.M. CYP719B1 is salutaridine synthase, the C-C phenol-coupling enzyme of morphine biosynthesis in opium poppy. J. Biol. Chem. 2009, 284, 24432-24442. [CrossRef]

44. Winzer, T.; Gazda, V.; He, Z.; Kaminski, F.; Kern, M.; Larson, T.R.; Li, Y.; Meade, F.; Teodor, R.; Vaistij, F.E.; et al. A Papaver somniferum 10- gene cluster for synthesis of the anticancer alkaloid noscapine. Science 2012, 336, 1704-1708. [CrossRef]

45. Chen, J.T. Phytochemical Omics in Medicinal Plants. Biomolecules 2020, 10, 936. [CrossRef] [PubMed]

46. Ma, X.; Meng, Y.; Wang, P.; Tang, Z.; Wang, H.; Xie, T. Bioinformatics-assisted, integrated omics studies on medicinal plants. Brief. Bioinform. 2020, 21, 1857-1874. [CrossRef] [PubMed]

47. Khoomrung, S.; Wanichthanarak, K.; Nookaew, I.; Thamsermsang, O.; Seubnooch, P.; Laohapand, T.; Akarasereenont, P. Metabolomics and Integrative Omics for the Development of Thai Traditional Medicine. Front. Pharmacol. 2017, 8, 474. [CrossRef] [PubMed]

48. Sahu, J.; Sen, P.; Choudhury, M.D.; Dehury, B.; Barooah, M.; Modi, M.K.; Talukdar, A.D. Rediscovering medicinal plants' potential with OMICS: Microsatellite survey in expressed sequence tags of eleven traditional plants with potent antidiabetic properties. Omics J. Integr. Biol. 2014, 18, 298-309. [CrossRef] [PubMed]

49. Kellner, A. Genome Sequence of Catharanthus Roseus. 2015. Available online: http://medicinalplantgenomics.msu.edu/ (accessed on 25 December 2019).

50. Kellner, F.; Kim, J.; Clavijo, B.J.; Hamilton, J.P.; Childs, K.L.; Vaillancourt, B.; Cepela, J.; Habermann, M.; Steuernagel, B.; Clissold, L.; et al. Genome-guided investigation of plant natural product biosynthesis. Plant J. 2015, 82, 680-692. [CrossRef]

51. Transcriptome Characterization, Sequencing, and Assembly of Medicinal Plants Relevant to Human Health. 2011. Available online: https:/ /apps.pharmacy.uic.edu/depts/pcrps/MedTranscriptomePlants/database.html (accessed on 20 December 2019).

52. One Thousand Plant Transcriptomes Initiative. One thousand plant transcriptomes and the phylogenomics of green plants. Nature 2019, 574, 679-685. [CrossRef]

53. Chu, H.Y.; Wegel, E.; Osbourn, A. From hormones to secondary metabolism: The emergence of metabolic gene clusters in plants. Plant J. 2011, 66, 66-79. [CrossRef]

54. Wurtele, E.; Chappell, J.; Jones, A.; Celiz, M.; Ransom, N.; Hur, M.; Rizshsky, L.; Crispin, M.; Dixon, P.; Liu, J.; et al. Medicinal plants: A public resource for metabolomics and hypothesis development. Metabolites 2012, 2, 1031-1059. [CrossRef]

55. Gahlaut, A.; Vikas, D.M.; Gothwal, A.; Kulharia, M.; Chhillar, A.K.; Hooda, V.; Dabur, R. Proteomics and metabolomics: Mapping biochemical regulations. Drug Invent. Today 2013, 5, 321-326. [CrossRef]

56. Seki, H.; Sawai, S.; Ohyama, K.; Mizutani, M.; Ohnishi, T.; Sudo, H.; Fukushima, E.O.; Akashi, T.; Aoki, T.; Saito, K.; et al. Triterpene functional genomics in licorice for identification of CYP72A154 involved in the biosynthesis of glycyrrhizin. Plant Cell 2011, 23, 4112-4123. [CrossRef]

57. Hao, D.C.; Xiao, P.G. Genomics and evolution in traditional medicinal plants: Road to a healthier life. EBO 2015, 11, 197-212. [CrossRef] [PubMed]

58. Boutanaev, A.M.; Moses, T.; Zi, J.; Nelson, D.R.; Mugford, S.T.; Peters, R.J.; Osbourn, A. Investigation of terpene diversification across multiple sequenced plant genomes. Proc. Natl. Acad. Sci. USA 2015, 112, E81-E88. [CrossRef] [PubMed]

59. Chen, S.; Sun, Y.; Xu, J.; Luo, H.; Sun, C.; He, L.; Cheng, X.; Zhang, B.; Xiao, P. Strategies of the study on herb genome program. Acta Pharm. Sin. (Yao Xue Xue Bao) 2010, 45, 807-812.

60. Velasco, R.; Zharkikh, A.; Troggio, M.; Cartwright, D.A.; Cestaro, A.; Pruss, D.; Pindo, M.; Fitzgerald, L.M.; Vezzulli, S.; Reid, J.; et al. A high quality draft consensus sequence of the genome of a heterozygous grapevine variety. PLoS ONE 2007, 2, e132. [CrossRef]

61. Jaillon, O.; Aury, J.M.; Noel, B.; Policriti, A.; Clepet, C.; Casagrande, A.; Choisne, N.; Aubourg, S.; Vitulo, N.; Jubin, C.; et al. French-Italian Public Consortium for Grapevine Genome C: The grapevine genome sequence suggests ancestral hexaploidization in major angiosperm phyla. Nature 2007, 449, 463-467.

62. Cai, J.; Liu, X.; Vanneste, K.; Proost, S.; Tsai, W.C.; Liu, K.W.; Chen, L.J.; He, Y.; Xu, Q.; Bian, C.; et al. The genome sequence of the orchid Phalaenopsis equestris. Nat. Genet. 2015, 47, 65-72. [CrossRef]

63. Chalhoub, B.; Denoeud, F.; Liu, S.; Parkin, I.A.; Tang, H.; Wang, X.; Chiquet, J.; Belcram, H.; Tong, C.; Samans, B.; et al. Early allopolyploid evolution in the post-Neolithic Brassica napus oilseed genome. Science 2014, 345, 950-953. [CrossRef]

64. Qin, C.; Yu, C.; Shen, Y.; Fang, X.; Chen, L.; Min, J.; Cheng, J.; Zhao, S.; Xu, M.; Luo, Y.; et al. Whole-genome sequencing of cultivated and wild peppers provides insights into capsicum domestication and specialization. Proc. Natl. Acad. Sci. USA 2014, 111, 5135-5140. [CrossRef] 
65. Kim, S.; Park, M.; Yeom, S.I.; Kim, Y.M.; Lee, J.M.; Lee, H.A.; Seo, E.; Choi, J.; Cheong, K.; Kim, K.T.; et al. Genome sequence of the hot pepper provides insights into the evolution of pungency in Capsicum species. Nat. Genet. 2014, 46, 270-278. [CrossRef]

66. Urasaki, N.; Takagi, H.; Natsume, S.; Uemura, A.; Taniai, N.; Miyagi, N.; Fukushima, M.; Suzuki, S.; Tarora, K.; Tamaki, M.; et al. Draft genome sequence of bitter gourd (Momordica charantia), a vegetable and me-dicinal plant in tropical and subtropical regions. DNA Res. 2017, 24, 51-58. [CrossRef]

67. Denoeud, F.; Carretero-Paulet, L.; Dereeper, A.; Droc, G.; Guyot, R.; Pietrella, M.; Zheng, C.; Alberti, A.; Anthony, F.; Aprea, G.; et al. The coffee genome provides insight into the convergent evolution of caffeine biosynthesis. Science 2014, 345, 1181-1184. [CrossRef] [PubMed]

68. Qian, J.; Song, J.; Gao, H.; Zhu, Y.; Xu, J.; Pang, X.; Yao, H.; Sun, C.; Li, X.; Li, C. The complete chloroplast genome sequences of the medicinal plant Salvia miltiorrhiza. PLoS ONE 2013, 8, e57607. [CrossRef]

69. Mahajan, R.T.C.M. Phyto-pharmacology of Ziziphus jujuba Mill-a plant review. Pharmacol. Rev. 2009, 3, $320-329$.

70. Li, Y.; Xu, C.; Lin, X. De novo assembly and characterization of the fruit transcriptome of Chinese Jujuba (Zizipus jujuba Mill) using 454 pyrosequencing and the development of novel trinucleotide SSR markers. PLoS ONE 2014, 9, e106438. [CrossRef]

71. Mochida, K.; Sakurai, T.; Seki, H.; Yoshida, T.; Takahagi, K.; Sawai, S.; Uchiyama, H.; Muranaka, T.; Saito, K. Draft genome assembly and annotation of Glycyrrhiza uralensis, a medicinal legume. Plant J. 2017, 89, 181-194. [CrossRef]

72. Yan, L.; Wang, X.; Liu, H.; Tian, Y.; Lian, J.; Yang, R.; Hao, S.; Wang, X.; Yang, S. The genome of Dendrobium officinale illu-minates the biology of the important traditional Chinese orchid herb. Mol. Plant 2015, 8, 922-934. [CrossRef]

73. Shivaraj, Y.; Govind, S.; Jogaiah, S.; Sannaningaiah, D. Functional analysis of medicinal plants using system biology approaches. Int. J. Pharm. Pharmaceut. Sci. 2015, 7, 41-43.

74. Ku, C.; Chung, W.C.; Chen, L.L.; Kuo, C.H. The Complete Plastid Genome Sequence of Madagascar Periwinkle Catharanthus roseus (L.) G. Don: Plastid Genome Evolution, Molecular Marker Identification, and Phylogenetic Implications in Asterids. PLoS ONE 2013, 8, e68518. [CrossRef] [PubMed]

75. He, Y.; Xiao, H.; Deng, C.; Xiong, L.; Yang, J.; Peng, C. The complete chloroplast genome sequences of the medicinal plant Pogostemon cablin. Int. J. Mol. Sci. 2016, 17, 820-830. [CrossRef]

76. Giddings, L.A.; Liscombe, D.K.; Hamilton, J.P.; Childs, K.L.; DellaPenna, D.; Buell, C.R.; O'Connor, S.E. A stereo selective hydroxylation step of alkaloid biosynthesis by a unique cytochrome P450 in Catharanthus roseus. J. Biol. Chem. 2011, 286, 16751-16757. [CrossRef]

77. Krishnan, N.M.; Pattnaik, S.; Jain, P.; Gaur, P.; Choudhary, R.; Vaidyanathan, S.; Deepak, S.; Hariharan, A.K.; Krishna, P.G.B.; Nair, J. A draft of the genome and four transcriptomes of a medicinal and pesticidal angiosperm Azadirachta indica. BMC Genom. 2012, 13, 464. [CrossRef] [PubMed]

78. Ma, Y.; Yuan, L.; Wu, B.; Li, X.; Chen, S.; Lu, S. Genome-wide identification and characterization of novel genes involved in terpenoid biosynthesis in Salvia miltiorrhiza. J. Exp. Bot. 2012, 63, 2809-2823. [CrossRef]

79. Xu, H.; Song, J.; Luo, H.; Zhang, Y.; Li, Q.; Zhu, Y.; Xu, J.; Li, Y.; Song, C.; Wang, B.; et al. Analysis 26 of the Genome Sequence of the Medicinal Plant Salvia miltiorrhiza. Mol. Plant 2016, 9, 949-952. [CrossRef] [PubMed]

80. Fridlender, M.; Kapulnik, Y.; Koltai, H. Plant derived substances with anticancer activity: From folklore to practice. Front. Plant Sci. 2015, 6, 799. [CrossRef] [PubMed]

81. Zhao, Y.; Yin, J.; Guo, H.; Zhang, Y.; Xiao, W.; Sun, C.; Wu, J.; Qu, X.; Yu, J.; Wang, X.; et al. The complete chloroplast genome provides insight into the evolution and polymorphism of Panax ginseng. Front. Plant Sci. 2015, 5, 696. [CrossRef] [PubMed]

82. Luo, J.; Hou, B.W.; Niu, Z.T.; Liu, W.; Xue, Q.Y.; Ding, X.Y. Comparative chloroplast genomes of photosynthetic orchids: Insights into evolution of the Orchidaceae and development of molecular markers for phylogenetic applications. PLoS ONE 2014, 9, e99016. [CrossRef] [PubMed]

83. Rastogi, S.; Kalra, A.; Gupta, V. Unravelling the genome of Holy basil an incomparable"elixir of life" of traditional Indian medicine. BMC Genom. 2015, 16, 413-431. [CrossRef] [PubMed]

84. Rastogi, S.; Meena, S.; Bhattacharya, A. De novo sequencing and comparative analysis of holy and sweet basil transcrip-tomes. BMC Genom. 2014, 15, 588-603. [CrossRef] [PubMed]

85. Upadhyay, A.K.; Chacko, A.R.; Gandhimathi, A.; Ghosh, P.; Harini, K.; Joseph, A.P.; Joshi, A.G.; Karpe, S.D.; Kaushik, S.; Ku-ravadi, N.; et al. Genome sequencing of herb Tulsi (Ocimum tenuiflorum) unravels key genes behind its strong me-dicinal properties. BMC Plant Biol. 2015, 15, 212. [CrossRef]

86. Rubin, B.E.; Ree, R.H.; Moreau, C.S. Inferring phylogenies from RAD sequence data. PLoS ONE 2012, 7, e33394. [CrossRef]

87. Kim, B.Y.; Park, H.S.; Kim, S.; Kim, Y.D. Development of microsatellite markers for Viscum coloratum (Santalaceae) and their application to wild populations. Appl. Plant Sci. 2017, 5, 1600102. [CrossRef]

88. Liu, W.; Yin, D.; Liu, J.; Li, N. Genetic diversity and structure of Sinopodophyl $\neg$ lum hexandrum (Royle) Ying in the Qinling Mountains, China. PLoS ONE 2014, 9, e110500.

89. Jiao, Y.; Paterson, A.H. Polyploidy-associated genome modifications during land plant evolution. Philos. Trans. R. Soc. Lond. B Biol. Sci. 2014, 369, 20130355. [CrossRef] [PubMed]

90. Hollister, J.D.; Greiner, S.; Wang, W.; Wang, J.; Zhang, Y.; Wong, G.K.; Wright, S.I.; Johnson, M.T. Recurrent loss of sex is associated with accumulation of deleterious mutations in Oenothera. Mol. Biol. Evol. 2015, 32, 896-905. [CrossRef] 
91. Cannon, S.B.; McKain, M.R.; Harkess, A.; Nelson, M.N.; Dash, S.; Deyholos, M.K.; Peng, Y.; Joyce, B.; Stewart, C.N., Jr.; Rolf, M. Multiple polyploidy events in the early radiation of nodulating and nonnodulating legumes. Mol. Biol. Evol. 2015, 32, 193-210. [CrossRef] [PubMed]

92. Yang, Y.; Moore, M.J.; Brockington, S.F.; Soltis, D.E.; Wong, G.K.; Carpenter, E.J.; Zhang, Y.; Chen, L.; Yan, Z.; Xie, Y. Dissecting molecular evolution in the highly diverse plant clade Caryo-phyllales using transcriptome sequencing. Mol. Biol. Evol. 2015, 32, 2001-2014. [CrossRef] [PubMed]

93. Hao, D.C.; Xiao, P.G.; Peng, Y.; Dong, J.; Liu, W. Evaluation of the chloroplast barcoding markers by mean and smallest interspecific distances. Pak. J. Bot. 2012, 44, 1271-1274.

94. Zhang, F.; Gao, Q.; Khan, G.; Luo, K.; Chen, S. Comparative transcriptome analysis of aboveground and underground tissues of Rhodiola algida, an important ethno-medicinal herb endemic to the Qinghai-Tibetan Plateau. Gene 2014, 553, 90-97. [CrossRef] [PubMed]

95. Hao, D.C.; Ge, G.; Xiao, P.; Zhang, Y.; Yang, L. The first insight into the tissue specific taxus transcriptome via Illumina second generation sequencing. PLOS ONE 2011, 6, e21220.

96. Hao, D.C.; Chen, S.L.; Osbourn, A.; Kontogianni, V.G.; Liu, L.W.; Jordán, M.J. Temporal transcriptome changes induced by methyl jasmonate in Salvia sclarea. Gene 2015, 558, 41-53. [CrossRef]

97. Hao, D.C.; Ma, P.; Mu, J.; Chen, S.; Xiao, P.; Peng, Y.; Huo, L.; Xu, L.; Sun, C. De novo characterization of the root transcriptome of a traditional Chinese medicinal plant Polygonum cuspidatum. Sci. China Life Sci. 2012, 55, 452-466. [CrossRef] [PubMed]

98. Yamazaki, M.; Mochida, K.; Asano, T.; Nakabayashi, R.; Chiba, M.; Udomson, N.; Yamazaki, Y.; Goodenowe, D.B.; Sankawa, U.; Yoshida, T.; et al. Coupling deep transcriptome analysis with untargeted metabolic profiling in Ophiorrhiza pumila to further the understanding of the biosynthesis of the anti-cancer alkaloid camptothecin and anthraquinones. Plant. Cell Physiol. 2013. [CrossRef] [PubMed]

99. Lau, W.; Sattely, E.S. Six enzymes from mayapple that complete the biosynthetic pathway to the etoposide aglycone. Science 2015, 349, 1224-1228. [CrossRef]

100. Gagne, S.J.; Stout, J.M.; Liu, E.; Boubakir, Z.; Clark, S.M.; Page, J.E. Identification of olivetolic acid cyclase from Cannabis sativa reveals a unique catalytic route to plant polyketides. Proc. Natl. Acad. Sci. USA 2012, 109, 1281-1286. [CrossRef]

101. Stout, J.M.; Boubakir, Z.; Ambrose, S.J.; Purves, R.W.; Page, J.E. The hexanoyl-CoA precursor for cannabinoid biosynthesis is formed by an acyl-activating enzyme in Cannabis sativa trichomes. Plant J. 2012, 71, 353-365. [CrossRef] [PubMed]

102. Kumar, M.; Meena, P.; Verma, S.; Kumar, M.; Kumar, A. Anti-tumour, anti-mutagenic and chemomodulatory potential of Chlorophytum borivilianum. A Pac. J. Cancer Prev. 2010, 11, 327-334.

103. Hao, D.C.; He, C.N.; Shen, J.; Xiao, P.G. Anticancer chemodiversity of Ranunculaceae medicinal plants: Molecular mecha-nisms and functions. Curr. Genom. 2017, 18, 39-59. [CrossRef] [PubMed]

104. Dinda, B.; Chowdhury, R.; Mohanta, D. Naturally occurring iridoids, secoiridoids and their bioactivity. Chem. Pharm. Bull. 2009, 57, 765-796. [CrossRef]

105. Geu-Flores, F.; Sherden, N.H.; Courdavault, V.; Burlat, V.; Glenn, W.S.; Wu, C.; Nims, E.; Cui, Y.; O'Connor, S.E. An alternative route to cyclic terpenes by reductive cyclization in iridoid biosynthesis. Nature 2012, 492, 138-142. [CrossRef]

106. Dinda, B.; Debnath, S.; Banik, R. Naturally occurring iridoids and secoiridoids. Chem. Pharm. Bull. 2011, 59, 803-833. [CrossRef]

107. Tundis, R.; Loizzo, M.R.; Menichini, F. Biological and pharmacological activities of iridoids: Recent developments. Med. Chem. 2008, 8, 399-420. [CrossRef] [PubMed]

108. Annadurai, R.S.; Neethiraj, R.; Jayakumar, V.; Damodaran, A.C.; Rao, S.N.; Katta, M.A.; Gopinathan, S.; Sarma, S.P.; Senthilkumar, V.; Niranjan, V.; et al. De novo transcriptome assembly (NGS) of Curcuma longa L. rhizome reveals novel transcripts related to anticancer and antimalarial terpenoids. PLoS ONE 2013, 8, e56217. [CrossRef] [PubMed]

109. Hao, D.C.; Xiao, P.G.; Liu, L.W.; Peng, Y.; He, C.N. Essentials of pharmacophylogeny: Knowledge pedigree, episte-mology and paradigm shift. China J. Chin. Mat. Med. 2015, 40, 1-8.

110. Gupta, P.; Goel, R.; Agarwal, A.K.; Asif, M.H.; Sangwan, N.S.; Sangwan, R.S.; Trivedi, P.K. Comparative tran-scriptome analysis of different chemotypes elucidates withanolide biosynthesis pathway from medicinal plant Withania somnifera. Sci. Rep. 2015, 5, 1861. [CrossRef] [PubMed]

111. Asano, T.; Kobayashi, K.; Kashihara, E.; Sudo, H.; Sasaki, R.; Iijima, Y.; Aoki, K.; Shibata, D.; Saito, K.; Yamazaki, M. Suppression of camptothecin biosynthetic genes results in metabolic modification of secondary products in hairy roots of Ophiorrhiza pumila. Phytochemistry 2012. [CrossRef] [PubMed]

112. Cui, G.; Huang, L.; Tang, X.; Zhao, J. Candidate genes involved in tanshinone biosynthesis in hairy roots of Salvia miltiorrhiza revealed by cDNA microarray. Mol. Biol. Rep. 2011, 38, 2471-2478. [CrossRef]

113. Wenping, H.; Yuan, Z.; Jie, S.; Lijun, Z.; Zhezhi, W. De novo transcriptome sequencing in Salvia miltiorrhiza to identify genes involved in the biosynthesis of active ingredients. Genomics 2011, 98, 272-279. [CrossRef]

114. Bunsupa, S.; Katayama, K.; Ikeura, E.; Oikawa, A.; Toyooka, K.; Saito, K.; Yamazaki, M. Lysine decarboxylase catalyzes the first step of quinolizidine alkaloid biosynthesis and coevolved with alkaloid production in Leguminosae. Plant Cell 2012, 24, 1202-1216. [CrossRef]

115. Facchini, P.J.; Bohlmann, J.; Covello, P.S.; De Luca, V.; Mahadevan, R.; Page, J.E.; Ro, D.K.; Sensen, C.W.; Storms, R.; Martin, V.J. Synthetic biosystems for the production of high-value plant metabolites. Trends Biotechnol. 2012, 30, 127-131. [CrossRef] 
116. Salim, V.; Yu, F.; Altarejos, J.; De Luca, V. Virus-induced gene silencing identifies Catharanthus roseus 7-deoxyloganic acid-7hydroxylase, a step in iridoid and monoterpene indole alkaloid biosynthesis. Plant J. 2013, 76, 754-765. [CrossRef]

117. Gongora-Castillo, E.; McKnight, T.D.; O'Connor, S.; Childs, K.L.; Buell, C.; Fedewa, G.; Hamilton, J.P.; Liscombe, D.K.; MagallanesLundback, M.; Mandadi, K.K.; et al. Development of transcriptomic resources for interrogating the biosynthesis of monoterpene indole alkaloids in medicinal plant species. PLOS ONE 2012, 7, e52506. [CrossRef]

118. Stavrinides, A.; Tatsis, E.C.; Foureau, E.; Caputi, L.; Kellner, F.; Courdavault, V.; O'Connor, S.E. Unlocking the diversity of alkaloids in Catharanthus roseus: Nuclear localization suggests metabolic channeling in secondary metabolism. Chem. Biol. 2015, 22, 336-341. [CrossRef]

119. Sun, H.; Liu, Y.; Gai, Y.; Geng, J.; Chen, L.; Liu, H.; Kang, L.; Tian, Y.; Li, Y. De novo sequencing and analysis of the cranberry fruit transcriptome to identify putative genes involved in flavonoid biosynthesis, transport and regulation. BMC Genom. 2015, 16, 652-669. [CrossRef]

120. Hyun, T.K.; Lee, S.; Rim, Y.; Kumar, R.; Han, X.; Lee, S.Y.; Lee, C.H.; Kim, J.Y. De-novo RNA sequencing and metabolite profiling to identify genes involved in anthocyanin biosynthesis in Korean black raspberry (Rubus coreanus Miquel). PLoS ONE 2014, 9, e88292. [CrossRef]

121. Bovy, A.; Schijlen, E.; Hall, R.D. Metabolic engineering of flavonoids in tomato: The potential for metabolomics. Metabolomics 2007, 3, 399-412. [CrossRef]

122. Hong, L.; Qian, Q.; Tang, D.; Wang, K.; Li, M.; Cheng, Z. A mutation in the rice chalcone isomerase gene causes the golden hull and internode 1 phenotype. Planta 2012, 236, 141-151. [CrossRef]

123. Muir, S.R.; Collins, G.J.; Robinson, S.; Hughes, S.; Bovy, A.; Ric De Vos, C.H.; van Tunen, A.J.; Verhoeyen, M.E. Overexpression of petunia chalcone isomerase in tomato results in fruit containing increased levels of flavonols. Nat. Biotechnol. 2001, 19, 470-474. [CrossRef]

124. Shi, S.G.; Yang, M.; Zhang, M.; Wang, P.; Kang, Y.X.; Liu, J.J. Genome-wide transcriptome analysis of genes involved in flavonoid biosynthesis between red and white strains of Magnolia sprengeri pamp. BMC Genom. 2014, 15, 706-776. [CrossRef]

125. Kaushik, N. Saponins of Chlorophytum species. Phytochem. Rev. 2005, 4, 191-196. [CrossRef]

126. Grimplet, J.; Cramer, G.R.; Dickerson, J.A.; Mathiason, K.; Van Hemert, J.; Fennell, A.Y. VitisNet. "Omics" integration through grapevine molecular networks. PLoS ONE 2009, 4, e8365. [CrossRef]

127. Lao, Y.; Wang, X.; Xu, N.; Zhang, H.; Xu, H. Application of proteomics to determine the mechanism of action of traditional Chinese medicine remedies. J. Ethnopharmacol. 2014, 155, 1-8. [CrossRef] [PubMed]

128. Zhang, A.; Sun, H.; Yuan, Y.; Sun, W.; Jiao, G.; Wang, X. An in vivo analysis of the therapeutic and synergistic properties of Chinese medicinal formula Yin-Chen-Hao-Tang based on its active constituents. Fitoterapia 2011, 82, 1160-1168. [CrossRef]

129. Wang, Y.; Yu, R.Y.; He, Q.Y. Proteomic analysis of anticancer TCMs targeted at mitochondria. Evid. Based Complement. Altern. Med. 2015, 2015, 539260. [CrossRef]

130. Huang, W.S.; Kuo, Y.H.; Chin, C.C.; Wang, J.Y.; Yu, H.R.; Sheen, J.M.; Tung, S.Y.; Shen, C.H.; Chen, T.C.; Sung, M.L. Proteomic analysis of the effects of baicalein on colorectal cancer cells. Proteomics 2012, 12, 810-819. [CrossRef]

131. Liu, Z.; Ma, L.; Zhou, G.B. The main anticancer bullets of the Chinese medicinal herb, thunder God vine. Molecules 2011, 16, 5283-5297. [CrossRef]

132. Liu, Y.; Song, F.; Wu, W.K.; He, M.; Zhao, L.; Sun, X.; Li, H.; Jiang, Y.; Yang, Y.; Peng, K. Triptolide inhibits colon cancer cell proliferation and induces cleavage and translocation of 14-3-3 epsilon. Cell Biochem. Funct. 2012, 30, 271-278. [CrossRef]

133. Valdiani, A.; Kadir, M.A.; Tan, S.G.; Talei, D.; Abdullah, M.P.; Nikzad, S. Nain-e Havandi (Andrographis paniculata) present yesterday, absent today: A plenary review on underutilized herb of Iran's pharmaceutical plants. Mol. Biol. Rep. 2012, 39, 5409-5424. [CrossRef]

134. Talei, D.; Valdiani, A.; Rafii, M.Y.; Maziah, M. Proteomic analysis of the salt-responsive leaf and root proteins in the anticancer plant Andrographis paniculata Nees. PLoS ONE 2014, 91, e112907. [CrossRef]

135. Lu, Z.; Song, Q.; Yang, J.; Zhao, X.; Zhang, X.; Yang, P.; Kang, J. Comparative proteomic analysis of anti-cancer mechanism by periplocin treatment in lung cancer cells. Cell Physiol. Biochem. 2014, 33, 859-868. [CrossRef] [PubMed]

136. Fang, H.Y.; Chen, S.B.; Guo, D.J.; Pan, S.Y.; Yu, Z.L. Proteomic identification of differentially expressed proteins in curcumin-treated MCF-7 cells. Phytomedicine 2011, 18, 697-703. [CrossRef]

137. Wang, N.; Wang, X.; Tan, H.Y.; Li, S.; Tsang, C.M.; Tsao, S.W.; Feng, Y. Berberine suppresses cyclin D1 expression through proteasomal degradation in human hepatoma cells. Int. J. Mol. Sci. 2016, 17, 1899. [CrossRef] [PubMed]

138. Chantarasriwong, O.; Batova, A.; Chavasiri, W.; Theodorakis, E.A. Chemistry and biology of the caged Garcinia xanthones. Chem. Eur. J. 2010, 16, 9944-9962. [CrossRef] [PubMed]

139. Chen, T.; Zhang, R.H.; He, S.C.; Xu, Q.Y.; Ma, L.; Wang, G.C.; Qiu, N.; Peng, F.; Chen, J.Y.; Qiu, J.X.; et al. Synthesis and antiangiogenic activity of novel gambogic acid derivatives. Molecules 2012, 17, 6249-6268. [CrossRef]

140. Anantachoke, N.; Tuchinda, P.; Kuhakarn, C.; Pohmakotr, M.; Reutrakul, V. Prenylated caged xanthones: Chemistry and biology. Pharm. Biol. 2012, 50, 78-91. [CrossRef] [PubMed]

141. Fu, W.M.; Zhang, J.F.; Wang, H.; Tan, H.S.; Wang, W.M.; Chen, S.C.; Zhu, X.; Chan, T.M.; Tse, C.M.; Leung, K.S.; et al. Apoptosis induced by 1,3,6,7-tetrahydroxy xanthone in Hepatocellular carcinoma and proteomic analysis. Apoptosis 2012, 12, 842-851. [CrossRef]

142. Fu, W.M.; Zhang, J.F.; Wang, H.; Xi, Z.C.; Wang, W.M.; Zhuang, P.; Zhu, X.; Chen, S.C.; Chan, T.M.; Leung, K.S.; et al. Heat shock protein 27 mediates the effect of 1,3,5-trihydroxy-13,13-dimethyl-2H- pyran [7,6-b] xanthone on mitochondrial apoptosis in hepatocellular carcinoma. J. Proteome. 2012, 75, 4833-4843. [CrossRef] 
143. Alsemari, A.; Alkhodairy, F.; Aldakan, A.; Al-Mohanna, M.; Bahoush, E.; Shinwari, Z.; Alaiya, A. The selective cytotoxic anticancer properties and proteomic analysis of Trigonella foenum-graecum. BMC Complement. Altern. Med. 2014, 14, 114. [CrossRef]

144. Jacobs, D.I.; Gaspari, M.; van der Greef, J.; van der Heijden, R.; Verpoorte, R. Proteome analysis of the medicinal plant Catharanthus roseus. Planta 2005, 221, 690-704. [CrossRef]

145. Raharjo, T.J.; Widjaja, I.; Roytrakul, S.; Verpoorte, R. Comparative proteomics of cannabis sativa plant tissues. J. Biomol. Tech. 2004, $15,97-106$.

146. Jenkins, C.; Orsburn, B. The Cannabis Proteome Draft Map Project. Int. J. Mol. Sci. 2020, 21, 965. [CrossRef]

147. Chen, M.; Yan, T.; Ji, L.; Dong, Y.; Sidoli, S.; Yuan, Z.; Cai, C.; Chen, J.; Tang, Y.; Shen, Q.; et al. Comprehensive Map of the Artemisia annua Proteome and Quantification of Differential Protein Expression in Chemotypes Producing High versus Low Content of Artemisinin. Proteomics 2020, 20, e1900310. [CrossRef] [PubMed]

148. Bryant, L.; Flatley, B.; Patole, C.; Brown, G.D.; Cramer, R. Proteomic analysis of Artemisia annua-Towards elucidating the biosynthetic pathways of the antimalarial pro-drug artemisinin. BMC Plant Biol. 2015, 15, 175. [CrossRef] [PubMed]

149. Kim, S.W.; Lee, S.H.; Min, C.W.; Jo, I.H.; Bang, K.H.; Hyun, D.Y.; Agrawal, G.K.; Rakwal, R.; Zargar, S.M.; Gupta, R. Ginseng (Panax sp.) proteomics: An update. Appl. Biol. Chem. 2017, 60, 311-320. [CrossRef]

150. Nagappan, A.; Karunanithi, N.; Sentrayaperumal, S.; Park, K.I.; Park, H.S.; Lee, D.H.; Kang, S.R.; Kim, J.A.; Senthil, K.; Natesan, S.; et al. Comparative root protein profiles of Korean ginseng (Panax ginseng) and Indian ginseng (Withania somnifera). Am. J. Chin. Med. 2012, 40, 203-218. [CrossRef]

151. Hartmann, T. From waste products to ecochemicals: Fifty years research of plant secondary metabolism. Phytochemistry 2007, 68, 2831-2846. [CrossRef]

152. Hao, D.C.; Xiao, P.G.; Liu, M.; Peng, Y.; He, C.N. Pharmaphylogeny vs. pharmacophylogenomics: Molecular phylogeny, evolution and drug discovery. Yao Xue Xue Bao 2014, 49, 1387-1394.

153. Croteau, R.; Kutchan, T.M.; Lewis, N.G. Natural Products (Secondary Metabolites). Biochem. Mol. Biol. Plants 2000, $24,1250-1319$.

154. Taiz, L.; Zeiger, E. Secondary Metabolites and Plant Defense. In Plant Physiology, 5th ed.; Sinauer Associates Inc., Publishers: Sunderland, MA, USA, 2006; pp. 369-400.

155. Baharum, S.N.; Bunawan, H.; Ghani, M.A.; Wan Aida Wan, M.; Noor, N.M. Analysis of the chemical composition of the essential oil of Polygonum minus Huds. Using two-dimensional gas chromatography-time-of-flight mass spectrometry (GC-TOF MS). Molecules 2010, 15, 7006-7015. [CrossRef]

156. Saito, K.; Matsuda, F. Metabolomics for functional genomics, systems biology, and biotechnology. Annu. Rev. Plant Biol. 2010, 61, 463-489. [CrossRef]

157. Ulrich-Merzenich, G.; Zeitler, H.; Jobst, D.; Panek, D.; Vetter, H.; Wagner, H. Application of the 'omic' technologies in phytomedicine. Phytomedicine 2007, 14, 70-82. [CrossRef]

158. Mukherjee, P.K.; Harwansh, R.K.; Bahadur, S.; Biswas, S.; Kuchibhatla, L.N.; Tetali, S.D.; Raghavendra, A.S. Metabo-lomics of medicinal plants- a versatile tool for standardization of herbal products and quality evaluation of Ayurvedic formulations. Curr. Sci. 2016, 111, 1624-1630. [CrossRef]

159. Kim, H.K.; Wilson, E.G.; Choi, Y.H.; Verpoorte, R. Metabolomics: A tool for anticancer lead-finding from natural products. Planta Med. 2010, 76, 1094-1102. [CrossRef]

160. Okada, T.; Mochamad Afendi, F.; Altaf-Ul-Amin, M.; Takahashi, H.; Nakamura, K.; Kanaya, S. Metabolomics of me-dicinal plants: The importance of multivariate analysis of analytical chemistry data. Curr. Comput. Aided Drug Des. 2010, 6, 179-196. [CrossRef]

161. Field, B.; Fiston-Lavier, A.S.; Kemen, A.; Geisler, K.; Quesneville, H.; Osbourn, A.E. Formation of plant metabolic gene clusters within dynamic chromosomal regions. Proc. Natl. Acad. Sci. USA 2011, 108, 16116-16121. [CrossRef] [PubMed]

162. Dixon, R.A.; Strack, D. Phytochemistry meets genome analysis, and beyond. Phytochemistry 2003, 62, 815-816. [CrossRef]

163. Yamada, T.; Matsuda, F.; Kasai, K.; Fukuoka, S.; Kitamura, K.; Tozawa, Y.; Miyagawa, H.; Wakasa, K. Mutation of a rice gene encoding a phenylalanine biosynthetic enzyme results in accumulation of phenylalanine and tryptophan. Plant Cell 2008, 20, 1316-1329. [CrossRef] [PubMed]

164. Noorolahi, S.M.; Sadeghi, S.; Mohammadi, M.; Azadi, M.; Rahimi, N.A.; Vahabi, F.; Arjmand, M.; Hosseini, H.; Mosallatpur, S.; Zamani, Z. Metabolomic profiling of cancer cells to Aloe vera extract by 1HNMR spectroscopy. J. Metabol. 2016, 2, 1-7. [CrossRef]

165. Xie, G.; Plumb, R.; Su, M.; Xu, Z.; Zhao, A.; Qiu, M.; Long, X.; Liu, Z.; Jia, W. Ultra-performance LC/TOF MS analysis of medicinal Panax herbs for metabolomic research. J. Sep. Sci. 2008, 31, 1015-1026. [CrossRef]

166. Goh, H.H.; Khairudin, K.; Sukiran, N.A.; Normah, M.N.; Baharum, S.N. Metabolite profiling reveals temperature effects on the VOCs and flavonoids of different plant populations. Plant Biol. 2016, 18, 130-139. [CrossRef]

167. Cragg, G.M.; Newman, D.J. Natural products: A continuing source of novel drug leads. Biochim. Biophys. Acta. 2013, 1830, 3670-3695. [CrossRef]

168. Newman, D.J.; Cragg, G.M. Natural products as sources of new drugs from 1981, to 2014. J. Nat. Prod. 2016, 79, 629-661. [CrossRef]

169. El-Naggar, S.A.; Abdel-Farid, I.B.; Elgebaly, H.A.; Germoush, M.O. Metabolomic profiling, antioxidant capacity and in vitro anticancer activity of some compositae plants growing in Saudi Arabia. Afr. J. Pharm. Pharmacol. 2015, 9, 764-774.

170. Marraffa, J.M. Amiodarone. In Encyclopedia of Toxicology, 3rd ed.; Wexler, P., Ed.; Academic Press: Cambridge, MA, USA, 2014; pp. 197-199. [CrossRef]

171. Meyer, U. From khellin to sodium cromoglycate-A tribute to the work of Dr. R. E. C. Altounyan (1922-1987). Die Pharm. 2002, $57,62-69$. 
172. Gregson, K.S.; Bennett, J.D. Drugs Acting on the Respiratory System. In Pharmacology and Therapeutics for Dentistry, 7th ed.; Dowd, F.J., Johnson, B., Mariotti, A., Eds.; Mosby: Maryland Heights, MO, USA, 2017; pp. 392-403. [CrossRef]

173. Jarukamjorn, K.; Nemoto, N. Pharmacological aspects of Andrographis paniculata on health and its major diterpenoid constituent andrographolide. J. Health Sci. 2008, 54, 370-381. [CrossRef]

174. Sun, Y.; Liu, K.; Zhang, T.; Sun, Y.; Chen, W.; Li, Q.; Chen, R.; Sun, X. The Neuroprotective Effect and Probable Mechanism of DL3-n-Butylphthalide in Brain Diseases. Integr. Med. Int. 2014, 1, 51-55. [CrossRef]

175. Aderibigbe, B.A. Design of Drug Delivery Systems Containing Artemisinin and Its Derivatives. Molecules 2017, 22, 323. [CrossRef]

176. Tallarida, R.J. Donnatal ${ }^{\circledR}$ (Robins). In TOP 200; Springer: New York, NY, USA, 1982. [CrossRef]

177. Sekhar, V.C.; Viswanathan, G.; Baby, S. Insights Into the Molecular Aspects of Neuroprotective Bacoside A and Bacopaside, I. Curr. Neuropharmacol. 2019, 17, 438-446. [CrossRef] [PubMed]

178. Li, F.; Jiang, T.; Li, Q.; Ling, X. Camptothecin (CPT) and its derivatives are known to target topoisomerase I (Top1) as their mechanism of action: Did we miss something in CPT analogue molecular targets for treating human disease such as cancer? Am. J. Cancer Res. 2017, 7, 2350-2394.

179. De Petrocellis, L.; Ligresti, A.; Moriello, A.S.; Allarà, M.; Bisogno, T.; Petrosino, S. Effects of cannabinoids and cannabinoid-enriched Cannabis extracts on TRP channels and endocannabinoid metabolic enzymes. Br. J. Pharmacol. 2011, 163, 1479-1494. [CrossRef]

180. Anand, P.; Bley, K. Topical capsaicin for pain management: Therapeutic potential and mechanisms of action of the new highconcentration capsaicin 8\% patch. Br. J. Anaesth. 2011, 107, 490-502. [CrossRef] [PubMed]

181. Azra, A.A.; Babak, D.H.; Hassan, E.; Ahmad, M. High in vitro production of anti-canceric indole alkaloids from periwinkle (Catharanthus roseus) tissue culture. Afr. J. Biotechnol. 2008, 7, 2834-2839.

182. Günter, G.; Desiree, A.; Brigitte, W.; Hanns, H. Effects of Quinine, Quinidine and Chloroquine on Human Muscle Nicotinic Acetylcholine Receptors. Front. Pharm. 2018, 9. [CrossRef]

183. Dubey, K.K.; Ray, A.R.; Behera, B.K. Production of demethylated colchicine through microbial transformation and scale-up process development. Process Biochem. 2008, 43, 251-257. [CrossRef]

184. Leung, Y.Y.; Yao Hui, L.L.; Kraus, V.B. Colchicine-Update on mechanisms of action and therapeutic uses. Semin. Arthritis Rheum. 2015, 45, 341-350. [CrossRef]

185. Luthra, P.M.; Singh, R.; Chandra, R. Therapeutic uses of Curcuma longa (turmeric). Indian J. Clin. Biochem. 2001, 16, 153-160. [CrossRef] [PubMed]

186. Hollman, A. Drugs for atrial fibrillation. Digoxin comes from Digitalis lanata. BMJ 1996, 312, 912. [CrossRef]

187. The American Society of Health-System Pharmacists. Digoxin. Available online: https://www.drugs.com/monograph/digoxin. html (accessed on 8 December 2016).

188. Chandrasekara, A.; Kumar, T.J. Roots and tuber crops as functional foods: A review on phytochemical constituents and their potential health benefits. Int. J. Food Sci. 2016, 3631, 647. [CrossRef]

189. Deshpande, H.A.; Bhalsing, S.R. Plant derived Novel Biomedicinal: Diosgenin. Int. J. Pharmacogn. Phytochem. Res. 2014, 6, 780-784.

190. Biscoping, J.; Bachmann-Mennenga, M.B. Lokalanästhetika: Vom Ester zum Isomer [Local anesthetics from ester to isomer]. Anasthesiol. Intensivmed. Notfallmed. Schmerzther. 2000, 35, 285-292. (In German) [CrossRef]

191. Behloul, N.; Wu, G. Genistein: A promising therapeutic agent for obesity and diabetes treatment. Eur. J. Pharmacol. 2013, 698, 31-38. [CrossRef]

192. Hartmann-Boyce, J.; Chepkin, S.C.; Ye, W.; Bullen, C.; Lancaster, T. Nicotine replacement therapy versus control for smoking cessation. Cochrane Database Syst. Rev. 2018, 5, CD000146. [CrossRef]

193. Barut, G.A.; Tunç, M.; Şahin, Ş.; Ulus, F.; Sazak, H. Effects of epidural morphine and levobupivacaine combination before incision and after incision and in the postoperative period on thoracotomy pain and stress response. Turk. J. Med. Sci. 2018, 48, 716-723. [CrossRef] [PubMed]

194. Rida, P.C.; LiVecche, D.; Ogden, A.; Zhou, J.; Aneja, R. The Noscapine Chronicle: A Pharmaco-Historic Biography of the Opiate Alkaloid Family and its Clinical Applications. Med. Res. Rev. 2015, 35, 1072-1096. [CrossRef] [PubMed]

195. Soni, D.; Grover, A. "Picrosides" from Picrorhiza kurroa as potential anti-carcinogenic agents. Biomed. Pharm. 2019, 109, 1680-1687. [CrossRef] [PubMed]

196. Rajeshkumar, N.V.; Kuttan, R. Inhibition of N-nitrosodiethylamine-induced hepatocarcinogenesis by Picroliv. J. Exp. Clin. Cancer Res. 2000, 19, 459-465.

197. Ansari, R.A.; Tripathi, S.C.; Patnaik, G.K.; Dhawan, B.N. Antihepatotoxic properties of picroliv: An active fraction from rhizomes of Picrorhiza kurrooa. J. Ethnopharmacol. 1991, 34, 61-68. [CrossRef]

198. Ardalani, H.; Avan, A.; Ghayour-Mobarhan, M. Podophyllotoxin: A novel potential natural anticancer agent. Avicenna J. Phytomedicine 2017, 7, 285-294. [PubMed]

199. Lobay, D. Rauwolfia in the Treatment of Hypertension. Integr. Med. 2015, 14, 40-46.

200. Li, Z.M.; Xu, S.W.; Liu, P.Q. Salvia miltiorrhiza Burge (Danshen): A golden herbal medicine in cardiovascular therapeutics. Acta Pharmacol. Sin. 2018, 39, 802-824. [CrossRef]

201. Weaver, B.A. How Taxol/paclitaxel kills cancer cells. Mol. Biol. Cell 2014, 25, 2677-2681. [CrossRef] 